Izv. prof. dr. sc. Snježana PEHAR

Pravni fakultet Sveučilišta u Mostaru

snjezana.pehar@pf.sum.ba

Doc. dr. sc. Marija VIDIĆ

Pravni fakultet Sveučilišta u Mostaru

marija.vidic@pf.sum.ba

Doc. dr. sc. Cvija JURKOVIĆ

Pravni fakultet Sveučilišta u Mostaru

cvija.jurkovic@pf.sum.ba
UDK: 347.771 (497.6)

Pregledni znanstveni rad

Primljen: 28. veljače 2019.

Prihvaćen:19. lipnja 2019.

\title{
POSTUPAK ZA PRIZNANJE PATENTA U PRAVU BOSNE I HERCEGOVINE
}

Sažetak: Postupak za priznanje i zaštitu patenta je kompliciran, dugotrajan, težak i skup. Postupak stjecanja, održavanja, sadržaj, evidencija prometa, prestanak i zaštita patenta na području Bosne i Hercegovine (BiH) propisan je Zakonom o patentu, te Pravilnikom o postupku za priznanje patenta.

Postupak priznanja patenta je posebni upravni postupak koji provodi Institut za intelektualno vlasništvo Bosne i Hercegovine. Na sva procesna pitanja koja nisu uređena Zakonom o patentu Bosne i Hercegovine i Pravilnikom o postupku za priznanje patenta, kao provedbenom propisu, primjenjuje se Zakon o upravnom postupku.

Iako su tri materijalnopravna uvjeta koja se moraju ispuniti kako bi se izum mogao patentirati univerzalno prihvaćena, još uvijek je pravo iskorištavanja patentiranog izuma teritorijalno ograničeno, tako da i patentna zaštita izuma u Europskoj uniji (EU) počiva na nacionalnom pravu država članica. Institut za intelektualno vlasništvo Bosne i Hercegovine vodi, pored Registra patenata, i Registar prijava patenata, stoga će se u radu analizirati značaj prijave u postupku priznanja patenta $i$ specifičnosti samog postupka zbog čega i jest reguliran posebnim zakonom.

Ključne riječi: izum, patent, upravni postupak, prijava patenta, Institut za intelektualno vlasništvo 


\section{Uvod}

Patent osigurava vlasniku isključivo pravo na izradu, korištenje, stavljanje u promet ili prodaju izuma zaštićenog patentom. Patent predstavlja pravo industrijskog vlasništva za izum koje je vremenski ograničeno na dvadeset, odnosno deset godina ako se radi o konsezualnom patentu. Patent je isprava kojom se zaštićuje isključivo pravo iskorištavanja nekog izuma.

Uobičajeno je da se o priznanju prava industrijskog vlasništva odlučuje u administrativnim postupcima, koje provodi nadležno tijelo državne vlasti specijalizirano za područje industrijskog vlasništva. ${ }^{1}$ Prihvaćeno je načelo da se u upravnom postupku odlučuje o stjecanju prava industrijskog vlasništva.

Patent se stječe odlukom nadležnog državnog tijela u posebnom upravnom postupku ${ }^{2} \mathrm{i}$ upisom $\mathrm{u}$ registar patenata, koji vodi to tijelo. Iako bi se u svim upravnim stvarima trebalo postupati prema Zakonu o upravnom postupku, ${ }^{3} \mathrm{kao}$ općem zakonu koji je jednak za sve one na koje se primjenjuje, ipak, kad se zakonodavac odluči za mogućnost i drukčijeg postupanja u pojedinim upravnim područjima, to se radi iznimno, pod strogim i preciznim zakonskim uvjetima ${ }^{4}$. Postupak priznanja patenta je specifičan, kompliciran i opravdava odluku zakonodavca za posebnim reguliranjem. Njegova valjanost je teritorijalno ograničena na državu čije tijelo ga je priznalo, ${ }^{5}$ odnosno proizvodi učinke samo na području na ko-

1 Matanovac Vučković, Romana, Žalba u postupcima za stjecanje prava industrijskog vlasništva i sudska nadležnost u odlučivanju o zakonitosti tih odluka - stanje nakon novele iz 2007. godine, dvojbe i perspektive, u: Matanovac Vučković, Romana (ur.) et al., Prilagodba hrvatskog prava intelektualnog vlasništva europskom pravu, Državni zavod za intelektualno vlasništvo, Narodne novine, Zagreb, 2007., str. 91.

2 U svakoj zemlji su na snazi brojni zakoni koji reguliraju pojedino upravno područje ili neke njegove dijelove (materijalni zakon) koji, uz odredbe materijalnopravne prirode, sadrže i posebne postupovne odredbe. Na taj način se odstupa od ograničenja koja su određena ZUP-om da se neka pitanja postupka za određeno upravno područje posebnim zakonom mogu regulirati drukčije nego je to određeno općim upravnim postupkom samo kad je to nužno za postupanje u tom upravnom području. Vidjeti: Ljubanović, Boris, Posebni upravni postupci u Republici Hrvatskoj, Modernizacija hrvatske uprave, Hrvatska javna uprava, god 6, 2006., str. 6. Službeni glasnik BiH, broj 29/02, 12/04, 88/07, 93/09, 4/13, 53/16. U daljnjem tekstu: ZUP. Ljubanović, Boris, Postupanje po novom zakonu o općem upravnom postupku i posebni upravni postupci, Modernizacija općeg upravnog postupka i javne uprave u Hrvatskoj, Institut za javnu upravu, Zagreb, Društveno veleučilište u Zagrebu, Biblioteka suvremena javna uprava, Knjiga broj 16, Zagreb, 2009., str. 144., dostupno na: http://iju.hr/Dokumenti/pub_28.pdf, posjećeno: 28. siječnja 2019. je načelo teritorijalnosti. Patent priznat na osnovu odredbi ZP je teritorijalno ograničeno 
jem djeluje pojedina registracija. ${ }^{6}$ Trajanje patenta je također ograničeno. Patent ima i druga ograničenja čiji je cilj uspostava razumne ravnoteže između interesa nositelja patenta i interesa društvene zajednice. Da bi patent za određeni izum mogao biti priznat, potrebno je da bude priznat čitav niz materijalnopravnih i formalnopravnih uvjeta. ${ }^{7}$

\subsection{Legislativni okvir za područje patenata}

Područje patenata u $\mathrm{BiH}$ uređeno je: Zakonom o patentu koji se primjenjuje od 1. siječnja 2011. i Pravilnikom o postupku za priznanje patenta i konsenzualnog patenta. ${ }^{8}$

Postupak priznanja patenta je posebni upravni postupak koji provodi Institut za intelektualno vlasništvo Bosne i Hercegovine. ${ }^{9} \mathrm{Na}$ sva proceduralna pitanja koja nisu uređena Zakonom o patentu primjenjivat će se odredbe ZUP-a. Administrativne takse u postupku za priznanje patenta su propisane Tarifom administrativ-

pravo koje vrijedi na teritoriju $\mathrm{BiH}$. Načelo teritorijalnosti proizlazi iz povijesne strukture intelektualnog vlasništva, koja je nastala u kontekstu neitegriranih nacionalnih sustava koja podrazumijeva državnu suverenost. Colabrese, B., „European patent with unitary effect but with variable law: regulating the right to patent for transnational inventions", REVISTA LEX MERCATORIA, Doctrina, praxis, Jurisprudencia y Legislacion, RLM no. 8, 2018., str. 29. Razlike nacionalnih zakona često su rezultirale situacijama kako izumitelji nisu bili podjednako zaštićeni u drugim zemljama. Krajem XIX. stoljeća, dolazi do sklapanja bilateralnih sporazuma kako bi se inovatori zaštitili, a oni će se pretvoriti u multilateralne sporazume o zaštiti intelektualnog vlasništva (primjerice: Pariška konvencija i niz drugih). Vidjeti: „Intellectual Property and private international Law“, general report (abbreviated version), International Academy of Comparative Law, Washington Congress 2010., str. 4. (prepared by Kono, Toshoyuki)

6 Matanovac Vučković, Romana, Ernst, Hano, „Prava na izumu koja mogu biti predmet ovrhe - hrvatska, europska i međunarodna perspektiva“, Nova pravna revija, časopis za domaće, njemačko i evropsko pravo, br. 2., 2013., str. 62. (u daljnjem tekstu: Matanovac Vučković, Ernst, Prava na izumu koja mogu biti predmet ovrhe - hrvatska, europska i medunarodna perspektiva).

7 Marković, Slobodan M., Popović, Dušan V., Pravo intelektualne svojine, Magistrat, Sarajevo, 2015., str. 117., 118. (u daljnjem tekstu: Marković, Popović). Službeni glasnik BiH, br. 105/10, 91/16. (u daljnjem tekstu: Pravilnik).

Institut za intelektualno vlasništvo Bosne i Hercegovine (u daljnjem tekstu: Institut) je pravni sljednik Instituta za standardizaciju, mjeriteljstvo i intelektualno vlasništvo Bosne i Hercegovine. U rujnu 2004. donesen je Zakon o osnutku Instituta za intelektualno vlasništvo Bosne i Hercegovine, Službeni glasnik BiH, broj 43/04., kojim su definirani položaj, nadležnosti i ovlaštenja Instituta. 
nih taksi. ${ }^{10}$ Troškovi postupka propisani su Odlukom o posebnim troškovima postupka za sticanje i održavanje prava industrijskoga vlasništva. ${ }^{11}$

Zakon o patentu sadrži i upućivanje na relevantne odredbe međunarodnih sporazuma kojih je $\mathrm{BiH}$ potpisnica. ${ }^{12} \mathrm{U}$ pogledu Europske patentne konvencije (EPC) iz 1973. godine, kako je mijenjana i dopunjavana, uz provedbene propise, za pristupanje ovoj konvenciji još uvijek nisu ispunjeni svi uvjeti. ${ }^{13}$ Institut za intelektualno vlasništvo je priredio Nacrt Zakona o izmjenama i dopunama zakona o patentu koji je dostavljen Europskoj patentnoj organizaciji (EPO), ${ }^{14}$ radi davanja

10 Službeni glasnik BiH, br. 5/95, 43/04 i 15/14.

11 Službeni glasnik BiH, br. 109/2010 i 29/02.

12 Zakon o patentu usuglašen je s međunarodnim konvencijama kojima administrira Svjetska organizacija za intelektualno vlasništvo (WIPO) u području patenata čija je članica Bosna i Hercegovina, odnosno s Pariškom konvencijom za zaštitu industrijskoga vlasništva, Ugovorom o suradnji u području patenata (PCT), Budimpeštanskim sporazumom o međunarodnome priznavanju depozita mikroorganizama u svrhu patentnoga postupka, Ugovorom o patentom pravu (PLT) sa WTO, Ugovorom o trgovinskopravnim aspektima prava intelektualnoga vlasništva (TRIPS) i sa pravnom stečevinom EU iz područja patenta i to: Direktivom (EU) broj 98/44 Europskog parlamenta i Vijeća od 6. srpnja 1998. o pravnoj zaštiti biotehnoloških izuma, Uredba (EU) broj 1768/92 Europskog parlamenta i Vijeća od 18. lipnja 1992., koja se odnosi na uvođenje svjedodžbe o dodatnoj zaštiti za lijekove namijenjene ljudima ili životinjama, kako je dopunjavana, Uredba (EU) broj 1610/96 Europskog parlamenta i Vijeća od 23. srpnja 1996., koja se odnosi na uvođenje svjedodžbe o dodatnoj zaštiti za proizvode za zaštitu bilja, kako je dopunjavana, Uredba (EU) broj 816/06 Europskog parlamenta i Vijeća od 17. svibnja 2006., o prinudnom licenciranju patenata koji se odnose na proizvodnju farmaceutskih proizvoda za izvoz u zemlje s problemima javnog zdravlja.

Izmjena zakona i podzakonskih akata kako bi se u potpunosti usuglasili s propisima EU i WTO, te pristupanje Europskoj patentnoj konvenciji i konvencijama u okviru Svjetske organizacije za intelektualno vlasništvo (WIPO) koje još uvijek nisu ratificirane navedeno je i u Srednjoročnom planu rada institucija, Institut za intelektualno vlasništvo $\mathrm{BiH}, 1$. 1. 2018. do 31. 12. 2020., str. 7. EPC je regionalni sporazum o patentima u smislu članka 45. st. 1. Ugovor o suradnji u oblasti patenta (Patent Cooperation Treaty - PCT), što znači da europski patenti mogu biti priznati na temelju međunarodne prijave podnesene u skladu s/ prema PCT-ju.

Europska patentna organizacija (EPO) je međuvladina organizacija osnovana 7. 10. 1977. na temelju Europske patentne konvencije. Više vidjeti na službenoj stranici EPO: https:// www.epo.org/about-us/governance.html, posjećeno: 19. siječnja 2019. EPO je utemeljena 1973. i djeluje od 1978. godine. Kaesling, Katharina, „The European Patent with Unitary Effect - A Unitary Patent protection for a unitary market?", UCL Journal of Law and Jurisprudence, str. 2., dostupno na: http://discovery.ucl.ac.uk/1470680/1/2UCLJLJ87\%20 -\%20European\%20Patents.pdf, posjećeno: 25. siječnja 2019. (u daljnjem tekstu: Kaesling, „The European Patent with Unitary Effect - A Unitary Patent protection for a unitary market?") 
mišljenja o usuglašenosti s odredbama Europske patentne konvencije. Nakon što se usvoji Zakon o izmjenama i dopunama Zakona o patentu bit će ispunjeni uvjeti za pristupanje Europskoj patentnoj konvenciji. ${ }^{15}$ Odnosno, tek usvajanjem izmjena i dopuna aktualnog Zakona, patentni će sustav biti usklađen s Europskom patentnom konvencijom (EPC), kako je mijenjana i dopunjavana. ${ }^{16}$

Djelovanje EU na području zaštite patenta zaostaje za drugim područjima zaštite intelektualnog vlasništva, i može se označiti specifičnim i kontroverznim. ${ }^{17} \mathrm{~Pa}$ tentna zaštita izuma u Europskoj uniji (EU) počiva na nacionalnom pravu država članica. Bez obzira na to jesu li ih odobrili nacionalni patentni uredi ili Europski patentni ured (EPO), pravo iskorištavanja patentiranog izuma je teritorijalno ograničeno, čiju supstancu određuje svaka država autonomno. ${ }^{18}$

\section{Predmet zaštite patentom}

Zakonom o patentu uređuje se pravna zaštita izuma patentom i konsenzualnim patentom, odnosno postupak za priznanje patenta i dodjelu konsenzualnog patenta. Ako Zakonom o patentu nije drugačije propisano, odredbe koje se odnose na patent na odgovarajući način primjenjuju se i na konsenzualni patent. ${ }^{19}$

15 Odgovori na Upitnik EU, Poglavlje 7: Pravo intelektualnog vlasništva, Patent, str. 21. Uz tehničku i financijsku pomoć EPO-a izrađene su nove baze podataka za evidentiranje europskog i nacionalnog patenta čime su ispunjeni tehnički uvjeti za pristupanje. Nakon što se ispune i pravni, očekuje se poziv Administrativnog vijeća Europske patentne organizacije za pristupanje konvenciji.

16 Također, Nacrt zakona predviđa i usklađivanje s Uredbom (EZ) 469/09 Europskog parlamenta i Vijeća od 6. svibnja 2009. godine koja se odnosi na uvođenje svjedodžbe o dodatnoj zaštiti za lijekove namijenjene ljudima ili životinjama, kojom je stavljena van snage Uredba (EZ) 1768/92, koja je bila relevantna za predmetni institut u vrijeme donošenja Zakona o patentu, pa se ovim izmjenama postiže usuglašenost s važećom Uredbom 469/09 i važećim propisima o zaštiti lijekova u Bosni i Hercegovini.

17 Kaesling, „The European Patent with Unitary Effect-A Unitary Patent protection for a unitary market?", str. 2.

18 Lamping, Matthias, Ullrich, Hanns, „The Impact of Brexit on Unitary Patent Protection and its Court", Max Planck Institute for Innovation and Competition Research Pater, No. 18 - 20., str. 7. (u daljnjem tekstu: Lamping, Ullrich, „The Impact of Brexit on Unitary Patent Protection and its Court").

19 Pojedini nacionalni sustavi, pored patenta poznaju još jedno pravo zaštite izuma, koje se naziva „mali patent“, „korisni model“, „konsenzualni patent“ ili „patent skraćenog roka trajanja“. Marković, Popović, Pravo intelektualne svojine, 2015., str.117.; Matanovac Vučković, Ernst, "Prava na izumu koja mogu biti predmet ovrhe - hrvatska, europska i međunarodna perspektiva“, str. 27. 
Materijalna prava nositelja patenta obuhvaćaju isključiva prava gospodarskog iskorištavanja izuma i pravo raspolaganja njime u skladu s odredbama ZP. Nositelj patenta je ex lege ovlašten za iskorištavanje izuma, te ima isključivo pravo na izradu, korištenje, stavljanje u promet ili prodaju izuma. ${ }^{20}$

\subsection{Izum kao predmet zaštite}

„Izum je intelektualno dobro koje se sastoji u uputstvu o tehničkom načinu i tehničkim sredstvima kojima se rješava određeni tehnički problem. ${ }^{21}$ Izumi se dijele prema različitim kriterijima. Tako razlikujemo izume proizvoda, izume postupka $^{22}$ i izume primjene. Određen značaj u patentnom pravu ima i podjela izuma na nezavisne i zavisne, te osnovne i dopunske. ${ }^{23}$

Sukladno čl. 6. st. 1. ZP, patent je svaki izum iz bilo kojeg područja tehnike koji je: 1) nov (čl. $8 \mathrm{ZP}), 2$ ) ima inventivnu razinu (čl. $10 \mathrm{ZP}), 3$ ) može se industrijski primijeniti (čl. $11 \mathrm{ZP}$ ). To su tri materijalnopravna uvjeta koja se moraju ispuniti kako bi se izum mogao patentirati. ${ }^{24}$ Ova tri uvjeta skoro su univerzalno prihvaćena i pravna teorija i praksa ih ujednačeno tumače.

Zakon ne daje definiciju izuma, već navodi nepotpunu listu svari koje se ne smatraju izumima (čl. 6. st. 6. ZP). Izumima se ne smatraju osobito: a) otkrića, znanstvene teorije i matematičke metode, b) estetske tvorevine, c) planovi, pravila i metode za izvođenje umnih aktivnosti, igara ili gospodarskih aktivnosti, ${ }^{25} \mathrm{~d}$ )

20 Zlatović, Dragan, „Ovlaštenja jedinstvenog patentnog suda i europsko patentno pravo“, u: Odvjetnik, br. 5/6/2015., str. 26. (u daljnjem tekstu: Zlatović, „Ovlaštenja jedinstvenog patentnog suda i europsko patentno pravo").

$21 \quad$ Marković, Popović, Pravo intelektualne svojine, 2015., str. 118.

22 Ako je patent izdan za postupak, njegovo se djelovanje odnosi i na proizvode neposredno dobivene tim postupkom. Vidjeti: TS Zagreb, P-20104/88 od 16. studenog 2000. Pregled sudske prakse iz oblasti zaštite prava intelektualnog vlasništva, Sarajevo, 2014., str. 71.

23 Više vidjeti: Marković, Popović, Pravo intelektualne svojine, 2015., str. 120. Isto tako: Miladinović, Pravo industrijske svojine, str. 55., 56.; Zlatović, „Ovlaštenja jedinstvenog patentnog suda i europsko patentno pravo", str. 25.

24 Prva dva uvjeta moraju biti ispunjena na dan podnošenja prijave patenta,odnosno na dan prvenstva prijave, dok treći mora biti zadovoljen najkasnije u trenutku donošenja rješenja za priznanje patenta. Marković, Popović, Pravo intelektualne svojine, 2015., str.124.

25 Patent se izdaje za izum koji je nov, ima inventivnu razinu i koji se može industrijski primijeniti, osim ako se radi o pravilima, uputama ili metodama za obavljanje poslova. TS Zagreb, P-31775/03 od 28. prosinca 2007. Pregled sudske prakse iz oblasti zaštite prava intelektualnog vlasništva, Sarajevo 2014., str. 75. 
programi računala, ${ }^{26}$ e) prezentacija informacija definirana samim sadržajem tih informacija.

Patent se priznaje i za izum koji se odnosi na: a) proizvod koji se sastoji od biološkog materijala ili koji sadrži biološki materijal, ${ }^{27}$ b) postupak kojim je taj biološki materijal proizveden, prerađen ili upotrijebljen, ${ }^{28} \mathrm{c}$ ) biološki materijal izoliran iz prirodne okoline ili proizveden tehničkim postupkom, čak i ako se ranije nalazio u prirodi.

\subsection{Izumi koji su izuzeti od patentne zaštite}

Svi patentni sustavi zabranjuju određene vrste izuma. Zabrane se uglavnom odnose na izume čije bi objavljivanje ili korištenje bilo suprotno zakonu ili moralu, na izume kemijske materije, izume lijekova, izume sredstava za ishranu, izume vezane za korištenje atomske energije i dr. ${ }^{29}$

U suvremenom patentnom pravu ne mogu se patentirati, u skladu s čl. 7. ZP: a) izumi životinjskih pasmina i biljnih sorti i bitno bioloških postupaka za dobivanje biljaka ili životinja, osim izuma nebioloških i mikrobioloških postupaka i proizvoda dobivenih tim postupcima kako je propisano u čl. 6. st. $4 . \mathrm{ZP}^{30}{ }^{30}$ pri čemu se, u smislu ovog zakona, pod mikrobiološkim postupkom podrazumijeva bilo koji postupak koji uključuje ili koji se provodi na mikrobiološkom materijalu ili čiji je proizvod mikrobiološki materijal, b) ljudsko tijelo, razni stupnjevi njegovog oblikovanja i razvoja ili jednostavno otkriće jednog od njegovih elemenata, uključujući sekvencu ili djelomičnu sekvencu gena, c) izumi koji se odnose na dijagnostičke ili kirurške postupke ili postupke liječenja koji se primjenjuju

26 Računarski program nije isključen od patentibilnosti ako u tijeku svoga rada na računalu može izazvati veći tehnički učinak koji nadilazi uobičajene fizičke učinke, ili koji nadilazi uobičajene fizičke interakcije programa i računala. Metodologija za pretraživanje i ispitivanje u području patenata, Institut za intelektualno vlasništvo $\mathrm{BiH}$, str. 6. i 7. (u daljnjem tekstu: Metodologija).

27 Biološki materijal je bilo koji materijal koji sadrži genetičku informaciju i koji se može razmnožavati sâm, ili se može razmnožavati u biološkom sistemu. Čl. 6. st. 3. ZP.

28 Postupak za dobivanje biljaka ili životinja bitno je biološki ako se u cijelosti sastoji od prirodnih postupaka kao što su križanje ili selekcija. Čl. 6. st. 5. ZP.

29 Marković, Popović, Pravo intelektualne svojine, 2015., str. 120. - 121. Isto tako: Miladinović, Pravo industrijske svojine, str. 53.

30 Izum koji se odnosi na biljke ili životinje smatrat ce se patentibilnim ako njegova tehnička izvodljivost nije ograničena na određenu biljnu sortu ili životinjsku pasminu i ako postupak ostvarivanja izuma nije bitno biološki. 
direktno na ljudskom ili životinjskom tijelu, osim proizvoda, posebno materija i smjesa koje se primjenjuju u navedenim postupcima. ${ }^{31}$

Neće se smatrati patentibilnim izumi čije bi komercijalno iskorištavanje bilo suprotno javnom poretku ili moralu, ali ne samo zbog toga što je takvo iskorištavanje zabranjeno zakonom ili drugim propisom. ${ }^{32}$

\subsection{Izumitelj}

Izumitelj je osoba koja je stvorila izum svojim stvaralačkim radom (čl. 12., st. 1. ZP). Kako je pronalazak intelektualno dobro, a intelektualno stvaralaštvo svojstveno samo čovjeku kao pojedincu, izumitelj može biti samo fizička osoba (ili grupa fizičkih osoba), a nikako pravna osoba. ${ }^{33}$ Pravo na zaštitu izuma pripada izumitelju ili njegovom pravnom sljedniku. ${ }^{34} \mathrm{Za}$ stjecanje svojstva izumitelja nije potrebno da izumitelj ima poslovnu sposobnost, što znači kako izumitelj može biti maloljetna ili duševno nesposobna osoba. ${ }^{35}$ Ako je izum nastao zajedničkim radom više izumitelja, pravo na patent pripada svim izumiteljima, ${ }^{36}$ jer se u praksi često događa da više osoba, udruženim intelektualnim naporima, stvore jedan izum. Sve osobe čijim je zajedničkim radom nastao izum zajednički su nositelji

$31 \quad$ Izum koji se odnosi na element izoliran iz ljudskog tijela ili proizveden tehničkim postupkom, uključujući sekvencu ili djelomičnu sekvencu gena, može biti patentibilan iako je strukturom jednak strukturi prirodnog elementa, industrijska primjenjivost sekvence ili djelomične sekvence gena mora biti razotkrivena u prijavi patenta, kako je izvorno podnesena. Čl. 7. st. 2. ZP.

32 Neće se smatrati patentibilnim izumi čije bi komercijalno iskorištavanje bilo suprotno javnom poretku ili moralu, ali ne samo zbog toga što je takvo iskorištavanje zabranjeno zakonom ili drugim propisom. Takvim izumima se osobito smatraju: a) postupci kloniranja ljudskih bića, b) postupci za modificiranje genetičkog identiteta matičnih ćelija ljudskih bića, c) upotreba ljudskih embrija u industrijske ili komercijalne svrhe i d) postupci za modificiranje genetičkog identiteta životinja koji bi vjerojatno prouzrokovali njihovu patnju bez ikakve bitne medicinske koristi za čovjeka ili životinju, kao i životinje koje su rezultat takvih postupaka. Čl. 7. st.3. i 4. ZP.

33 Marković, Popović, Pravo intelektualne svojine, 2015., str. 129. Isto tako: Miladinović, Pravo industrijske svojine, str. 63.

34 Čl. 12., st. 2. ZP.

35 Marković, Popović, Pravo intelektualne svojine, 2015., str. 129. Isto tako: Miladinović, Pravo industrijske svojine, str. 63.

36 Čl. 12., st. 3. ZP. Suradnici na stvaranju izuma, koji ne ispunjavaju taj uvjet, nisu izumitelji (primjerice financijeri, stručni konzultanti). Marković, Popović, Pravo intelektualne svojine, 2015., str.129. 
jedinstvenog prava na patentnu zaštitu.

Izumitelj ima moralno pravo u statusu izumitelja da bude naveden u prijavi patenta, svim ispravama koje se izdaju za priznati patent, te u odgovarajućim registrima. ${ }^{37}$ Nositelj patenta stječe isključivo pravo korištenja izuma tek od priznanja i upisa priznatog prava u odgovarajući registar, s tim da ovo pravo vrijedi unatrag od dana podnošenja prijave. Od podnošenja uredne prijave pa do odluke Instituta, podnositelj prijave stječe privremena prava, a trećim osobama može zabraniti da se koriste izumom samo ako se u parnici utvrdi da se radi o izumu koji se može zaštiti patentom. ${ }^{38}$

\section{Postupak za priznanje patenta}

\subsection{Ovlaštenja Instituta}

Kada se govori o postupku stjecanja patenta, treba imati u vidu mogućnost različitih postupaka za stjecanje patenta u ovisnosti želi li se stjecanje prava $\mathrm{s}$ učinkom na teritoriju svoje države ili s učinkom u više država, ${ }^{39}$ budući da razlikujemo nacionalne, regionalne i međunarodne rute stjecanja patenta. Međutim, kako je ovo pravo teritorijalno ograničeno naglasak u radu će biti na prijavi patenta, odnosno postupku stjecanja patenta u $\mathrm{BiH}$ putem podnošenja prijave Institutu s učinkom na teritorij $\mathrm{BiH}$.

Postupak za stjecanje, održavanje, prestanak i evidenciju prometa patenta, odnosno konsenzualnog patenta vodi Institut za intelektualno vlasništvo Bosne i Hercegovine.

Za oblast patenata Institut vodi sljedeće registre: Registar prijava patenata, Registar patenata.

Protiv odluka Instituta donesenih u prvom stupnju dopuštena je žalba o kojoj

$37 \quad$ Ako je izum koji se štiti rezultat stvaralačkog rada više osoba, u prijavi patenta i svim ispravama sve te osobe se navode kao izumitelji. Čl. 13.ZP.

38 Privredni sud Hrvatske, Pž-1961/95 od 10. kolovoza 1993. Pregled sudske prakse iz oblasti zaštite prava intelektualnog vlasništva, Sarajevo 2014., str. 102. Podnositelj uredne prijave za priznanje patenta ima privremeno pravo zaštite izuma koji je predmet prijave. Sud može prekinuti postupak do odluke nadležnog tijela za patente, ali samo ako rezultati postupka ukazuju da za to postoje valjani razlozi. Privredni sud Hrvatske, Pž-3465/93, od 4. 1. 1994. Pregled sudske prakse iz oblasti zaštite prava intelektualnog vlasništva, Sarajevo 2014., str. 102.

39 Miladinović, Pravo industrijske svojine, str. 68. 
odlučuje Komisija za žalbe Instituta. Protiv rješenja Instituta donesenog u drugom stupnju žalba nije dopuštena, ali se može pokrenuti upravni spor podnošenjem tužbe Sudu Bosne i Hercegovine. ${ }^{40}$

Za sve radnje u postupku stjecanja, održavanja, evidencije prometa i prestanka patenta, kao i za pružanje informacijskih usluga plaćaju se takse suglasno važećem propisu kojim se ureduju državne administrativne takse i naknade posebnih troškova postupka u visini određenoj posebnom tarifom, koju donosi Ministarstvo vanjske trgovine i ekonomskih odnosa $\mathrm{BiH}$, na prijedlog direktora Instituta. Ako u postupku priznanja patenta takse ni troškovi postupka ne budu plaćeni, prijava patenta smatrat će se povučenom, a u slučaju neplaćanja taksi i troškova postupka za održavanje patenta i prava iz prijave patenta, to pravo prestaje važiti. Za podnošenje žalbe plaćaju se taksa i troškovi postupka u skladu s posebnim propisima. Ako taksa i troškovi postupka ne budu plaćeni prije isteka roka za žalbu, Institut će pozvati podnositelja da ih plati u roku od 15 dana. Ako taksa i troškovi postupka ne budu plaćeni, smatra se da žalba nije podnesena. ${ }^{41}$

Sukladno čl. 16. ZP, pitanja postupka koji se vodi pred Institutom bliže se ureduju provedbenim propisima. Za pojedina pitanja koja nisu uređena ZP i provedbenim propisom primjenjivat će se odredbe Zakona o upravnom postupku (ZUP).

Pored toga, potrebno je naglasiti odredbu čl. 122. ZP, kojom se određuje kako odredbe međunarodnih ugovora u vezi s patentima, kojima je pristupila Bosna i Hercegovina, primjenjuju se na predmete koje tretira ZP i u slučaju sukoba $s$ odredbama ZP primjenjuju se odredbe međunarodnih ugovora.

\subsection{Pokretanje postupka}

Postupak za priznanje patenta pokreće se podnošenjem Institutu prijave za priznanje patenta. Prijava se podnosi u pisanom obliku, direktno ili poštom, a može se podnijeti i telefaksom ili na službeni $e$-mail Instituta. ${ }^{42}$

Prijave se uzimaju u postupak ispitivanja redoslijedom njihovog podnošenja. ${ }^{43}$ Iznimno, prijava se može ispitivati prema hitnom postupku u slučaju sudskog ili

40 U Nacrtu se predviđa ispravka u smislu da se navedenom izmjenom ispravlja greška u pisanju, jer je drugostupanjski organ „Povjerenstvo za žalbe Instituta“, kako je utvrđeno u stavku 3., i to Povjerenstvo donosi drugostupanjske odluke, a ne Institut.

$41 \quad$ Čl. 15. ZP.

42 Čl. 2., st. 1. i 2. Pravilnika.

43 Podnošenje prijave je inicijalna radnja, kojom se pokreće postupak za priznanje patenta. Miladinović, Pravo industrijske svojine, str. 55. 
drugog spora u kojem završetak postupka po prijavi predstavlja rješenje prethodnog pitanja. Institut će provesti hitno ispitivanje na osnovu podnesenog obrazloženog zahtjeva s dokazima. ${ }^{44}$

Pravilo je da se za svaki izum podnosi posebna prijava. Jednom prijavom može se zahtijevati zaštita za više izuma samo ako su ti izumi međusobno tako povezani da ostvaruju jedinstvenu izumiteljsku zamisao (jedinstvo izuma). ${ }^{45}$

Prijava patenta ${ }^{46}$ mora sadržavati:

1. zahtjev za priznanje patenta,

2. opis izuma,

3. jedan ili više patentnih zahtjeva,

4. crteže na koje se pozivaju opis izuma i patentni zahtjevi,

5. sažetak.

Zahtjev za priznanje patenta mora sadržavati: a) izričitu naznaku da se zahtijeva priznanje patenta, b) naziv izuma koji odražava njegovu bit, c) podatke o podnositelju prijave, d) podatke o izumitelju, odnosno napomenu da izumitelj ne želi biti naveden u prijavi. ${ }^{47}$

Izum se mora opisom otkriti na način dovoljno jasan i detaljan, tako da ga stručnjak iz odgovarajuće oblasti može izvesti. Uvjetu razotkrivanja izuma mora udovoljiti opis izuma uz pomoć crteža, ako se na njih poziva. ${ }^{48}$ Ako se izum odnosi na živi biološki materijal i ako ga nije moguće primijeniti na osnovu opisa izuma, smatrat će se da opis izuma ispunjava uvjet ako je uzorak prirodno obnovljivog živog biološkog materijala deponiran u nadležnoj ustanovi najkasnije na datum podnošenja prijave patenta. ${ }^{49}$

\footnotetext{
$44 \quad$ Čl. 17. ZP.

$45 \quad$ Čl. 18. ZP; Marković, Popović, Pravo intelektualne svojine, 2015., str. 138.

$46 \quad$ Sukladno čl. 19. ZP, prijava patenta mora biti sastavljena na jednom od jezika koji su u službenoj upotrebi u BiH. Ako je tekst prijave podnesen na stranom jeziku, Institutu se mora dostaviti prijevod teksta prijave na jedan od jezika koji su u službenoj upotrebi u $\mathrm{BiH}$.

47 Nacrt zakona predviđa u članku 20. stavak (2) iza točke d) dodaje se nova točka e) koja glasi „naznaku na kojem se od jezika u službenoj uporabi u BiH prijava patenta podnosi, odnosno objavljuje patent.“

48 Opisom se mora osigurati da prijava sadrži dostatne tehničke podatke koji će omogućiti da stručnjak odgovarajućeg područja može izvesti izum i omogućiti osobi koja čita prijavu da razumije koliko je doprinos izumitelja stanju tehnike, kako bi se izum mogao procijeniti. Metodologija, str. 24.
}

49 Opisivanje izuma je detaljno regulirano čl. 5. Pravilnika. 
Patentnim zahtjevima određuju se obujam i predmet zaštite izuma. ${ }^{50}$ Oni moraju biti jasni, sažeti i u cijelosti potkrijepljeni opisom izuma i crtežima ako postoje. Patentni zahtjevi mogu biti nezavisni i zavisni. Nezavisni patentni zahtjevi sadržavaju nova bitna obilježja izuma. Zavisni patentni zahtjevi sadržavaju specifična obilježja izuma koji je određen u nezavisnom ili drugom zavisnom patentnom zahtjevu. Ovaj dio je najbitniji i ne treba ga jednačiti sa zahtjevom za priznanje patenta. ${ }^{51}$

Sažetak je kratak sadržaj suštine izuma koji služi isključivo u svrhu tehničkog informiranja i nema utjecaja na obujam tražene zaštite. ${ }^{52}$

Utvrđivanje datuma podnošenja prijave ima poseban značaj, kako u procesnopravnom tako i u materijalnopravnom smislu. ${ }^{53}$ Za priznanje datuma podnošenja prijave potrebno je da prijava podnesena Institutu na taj datum sadrži sljedeće: a) izričitu naznaku da se zahtijeva priznanje patenta, b) podatke o podnositelju prijave, c) dio prijave koji na prvi pogled izgleda kao opis izuma, iako taj opis ne zadovoljava sve uvjete propisane ZP i provedbenim propisom. ${ }^{54}$

Obzirom na zabranu dvostrukog patentiranja istog izuma, patentno pravo daje prvenstvo u pogledu prava na zaštitu onoj osobi koja je prva prijavila izum za zaštitu. ${ }^{55} \mathrm{U}$ čl. 24. do 31 . ZP određeni su uvjeti za priznavanje prava prvenstva.

Od datuma koji je utvrđen kao datum podnošenja prijave patenta iz čl. 22. ZP, pod uvjetom da je prijava objavljena u skladu s odredbama čl. 37. ZP, podnositelj prijave ima pravo prvenstva u pogledu svakog drugog podnositelja koji za isti izum podnese prijavu kasnije. Prvenstvo vrijedi od datuma podnošenja prijave patenta Institutu, osim u slučaju kad su zadovoljeni uvjeti za priznanje prava prvenstva iz čl. 25. ZP.

$50 \quad$ Patentni zahtjevi moraju biti sastavljeni tako da definiraju izum isključivo tehničkim karakteristikama, što je detaljno regulirano čl. 6. Pravilnika, dok čl. 7. određuje crteže koji se prilažu u prijavi.

51 Ovaj zahtjev se ne piše tako da ga razumiju laici ili pravnici, već stručnjaci iz odgovarajućeg područja tehnike kojoj izum pripada. Isto tako: Miladinović, Pravo industrijske svojine, str. 71.

52 Mora učinkovito poslužiti kao instrument za pretragu u određenom području tehnike, posebice da se na temelju njega ocijeni potreba za uvidom u kompletnu prijavu patenta. Čl. 8. Pravilnika.

53 Više vidjeti: Miladinović, Pravo industrijske svojine, str. 81.

54 Čl. 22. ZP.

55 Marković, Popović, Pravo intelektualne svojine, 2015., str. 142. Isto tako: Miladinović, Pravo industrijske svojine, str. 79. 
Kako bi zahtjev za priznavanje prava prvenstva bio uredan, moraju se ispuniti određeni uvjeti: ranija prijava mora biti podnesena u nekoj od država članica Pariške unije (ili za tu državu), odnosno u državi članici WTO (ili za tu državu), ranija prijava čije se prvenstvo zahtijeva mora biti podnesena od strane podnositelja prijave podnesene u $\mathrm{BiH}$ (ili njegovog pravnog prednika), ranija prijava mora biti podnesena najviše 12 mjeseci prije datuma podnošenja prijave u $\mathrm{BiH}$ i ranija prijava mora biti „prva prijava“ podnesena za izum koji je isti kao izum na koji se odnosi prijava patenta podnesena u $\mathrm{BiH} .{ }^{56}$

Jedno od značajnih naslijeđa Pariške konvencije je uvođenje instituta međunarodnog prvenstva u patentne sustave, što je prihvaćeno i u čl. 25. ZP. Svakoj fizičkoj ili pravnoj osobi koja u nekoj državi članici Pariške unije za zaštitu industrijskog vlasništva, odnosno državi članici Svjetske trgovinske organizacije (WTO) podnese urednu prijavu za isti izum priznat će se pravo prvenstva u Bosni i Hercegovini, ako to zatraži u roku od 12 mjeseci računajući od dana podnošenja prve prijave. Svrha ovog instituta je olakšati istom prijavitelju stjecanje patentne zaštite u više država. ${ }^{57}$

Urednom prijavom smatra se prijava čiji je datum podnošenja utvrđen u skladu s nacionalnim zakonodavstvom države članice Pariške unije ili članice WTO-a u kojoj je podnesena, ili u skladu s međunarodnim ugovorom zaključenim između država članica bez obzira na njenu kasniju pravnu sudbinu.

Kasnija prijava patenta koja je podnesena u istoj ili za istu državu smatrat će se prvom prijavom za potrebe utvrđivanja prava prvenstva u onom dijelu koji se odnosi na predmet izuma prve prijave ako je na datum podnošenja kasnije prijave prva prijava, koja je služila za utvrđivanje prava prvenstva, povučena, odbijena ili odbačena prije nego što je postala dostupna javnosti i nije proizvela nikakve pravne učinke. Prva prijava patenta ne može više služiti kao osnova za zahtijevanje prava prvenstva.

Kako bi se ispunili procesnopravni uvjeti, podnositelj prijave patenta koji se u $\mathrm{BiH}$ namjerava koristiti pravom prvenstva dužan je sukladno čl. 26. ZP, Institutu podnijeti: a) zahtjev za priznanje prava prvenstva koji sadržava bitne podatke o prvoj prijavi čije se prvenstvo zahtijeva ${ }^{58}$, najkasnije do isteka roka od dva mjeseca od datuma podnošenja prijave u Bosni i Hercegovini i b) prijepis prve prijave

56 Metodologija, str. 22. Priručnik iz oblasti intelektualnog vlasništva za sudije, Bosna i Hercegovina, DEA print, Sarajevo, 2013., str. 159. (u daljnjem tekstu: Priručnik).

57 Tako što će smanjiti mogućnost da u razdoblju između podnošenja prijava patenta u dvije ili više država izum prestane ispunjavati uvjete za zaštitu. Marković, Popović, Pravo intelektualne svojine, 2015., str. 143.

58 Broj i datum podnošenja prijave, državu članicu Pariške unije ili članicu WTO-a u kojoj je ili za koju je prijava podnesena. Čl. 18. Pravilnika određuje što zahtjev mora sadržavati. 
ovjeren od nadležnog organa države članice Pariške unije ili članice WTO-a u kojoj je ili za koju je prijava podnesena najkasnije do isteka roka od tri mjeseca od datuma podnošenja zahtjeva za priznanje prava prvenstva, ili četiri mjeseca od datuma podnošenja prijave patenta u $\mathrm{BiH}$, ili 16 mjeseci od najranijeg datuma zahtijevanih prvenstava, zavisno od toga koji od navedenih rokova ranije istječe. ${ }^{59}$

Ako je prijava patenta za koju se zahtijeva pravo prvenstva iz prve prijave podnesena na datum koji je kasniji od datuma na koji istječe period prvenstva iz čl. 25. st. 1. ZP, podnositelj prijave patenta može podnijeti zahtjev za obnavljanje prava prvenstva. ${ }^{60}$

Institut će usvojiti zahtjev za obnavljanje prava prvenstva pod uvjetom da podnositelj: a) navede razloge koji potvrđuju da je do propuštanja roka u kojem se priznaje period prvenstva došlo usprkos dužnoj pažnji koju su zahtijevale okolnosti i b) plati takse i troškove postupka. ${ }^{61}$

Zahtjev za priznanje prava prvenstva može se odnositi samo na ona obilježja izuma koja su sadržana u prvoj prijavi ili prijavama čije se prvenstvo zahtijeva. Ako se pojedina obilježja izuma na koje se odnosi zahtjev za priznanje prava prvenstva ne nalaze u patentnim zahtjevima sadržanim u prvoj prijavi, odnosno prijavama, pravo prvenstva priznat će se ako se ta obilježja mogu utvrditi iz svih sastavnih dijelova prijave. ${ }^{62}$

U skladu s čl. 27. ZP, podnositelj prijave patenta može podnijeti zahtjev za ispravak ili dopunu zahtjeva za priznanje prava prvenstva u roku od 16 mjeseci od datuma prava prvenstva ili, ako bi ispravak ili dopuna prouzrokovala promjenu datuma prava prvenstva, u roku od 16 mjeseci od tako promijenjenog datuma prvenstva, koje god od šesnaestomjesečnog perioda istječe prije, pod uvjetom da je takav zahtjev podnesen u roku od četiri mjeseca od datuma podnošenja prijave patenta. ${ }^{63}$ Ako je radi ispravke ili dopune zahtjeva za priznanje prava prvenstva

$59 \quad$ Metodologija, str. 24.

60 Ovaj zahtjev se može podnijeti u roku od dva mjeseca od datuma istjecanja perioda prvenstva. Čl. 26. st. 3.

61 Institut obavještava podnositelja o razlozima zbog kojih zahtjev za obnavljanje prava prvenstva namjerava odbiti u cijelosti ili djelomično, te ga poziva da se u roku od mjesec dana od dana primanja poziva izjasni o tim razlozima.

Čl. 30. ZP. U skladu s čl. 31. ZP, kao datum podnošenja prijave patenta Institutu smatra se datum priznatog prava prvenstva. Na zahtjev podnositelja prijave Institut izdaje uvjerenje o pravu prvenstva prijave. Čl. 34. ZP i čl. 18. Pravilnika. ne plati takse i troškove postupka, zahtjev se odbacuje zaključkom. 
promijenjen datum prava prvenstva koje se zahtijeva, rokovi se računaju od promijenjenog datuma prvenstva.

U skladu s čl. 29. ZP, moguće je zahtijevati višestruko pravo prvenstva. Podnositelj prijave u $\mathrm{BiH}$ može zahtijevati priznanje višestrukog prava prvenstva na osnovu više ranije podnesenih prijava $u$ jednoj ili više zemalja članica Pariške unije ili WTO. U svim slučajevima, najranija prijava mora biti podnesena najviše 12 mjeseci prije datuma podnošenja.

Prijava patenta zaprima se na Protokol Instituta. Administrativno osoblje će na dokumente upisati datum, sat i klasifikacijski broj upravnog spisa. U bazu podataka unose se podatci o podnositelju prijave i vrsti predmeta. ${ }^{64}$ Podnositelj odmah dobiva potvrdu o podnošenju dokumenata koji su navodna patentna prijava. Odsjek za patente Instituta će sve dokumente koji čine prijavu patenta skenirati i pohraniti u PDF-formatu u baze podataka Instituta.

Nakon što referent utvrdi kako prijava ispunjava uvjete za utvrđivanje datuma podnošenja, dodijelit će joj broj ${ }^{65}$ o čemu se izdaje zaključak kojim se utvrđuje datum podnošenja prijave patenta. Potom će se prijava kojom je zaključkom utvrđen datum podnošenja upisati u Registar prijava patenata sukladno čl. 33. st. 1. ZP

Ako prijava ima formalne nedostatke, te ne ispunjava uvjete za priznanje datuma podnošenja, Institut poziva podnositelja da u roku od mjesec dana od dana primanja poziva ukloni te nedostatke. Ako ne postupi u skladu s pozivom Instituta u navedenom roku, prijava patenta odbacuje se zaključkom. Ako podnositelj ukloni nedostatke $\mathrm{u}$ roku, Institut donosi zaključak kojim se datum primanja zahtijevanih ispravaka utvrđuje kao datum podnošenja prijave patenta. ${ }^{66}$

Sukladno čl. 33. ZP, prijava patenta kojoj je zaključkom utvrđen datum podnošenja upisuje se u Registar prijava patenata, koji u elektronskoj formi vodi Institut. ${ }^{67}$

\footnotetext{
$64 \quad$ Metodologija, str. 58.

65 Primjerice: BAP193050A, gdje je: BA - međunarodna oznaka države, A - oznaka za vrstu prava - patent, 19 - oznaka godine podnošenja prijave, 3050 - redni broj, A - oznaka za prijavu patenta. Metodologija, str. 59.

${ }_{66}$ Kad se u prijavi patenta poziva na crteže koji nisu sadržani u prijavi, ili ako podnositelj nije platio troškove, odnosno nije dostavio prijevod prijave patenta na jednom od jezika koji su u službenoj upotrebi u BiH, dužan je te nedostatke ukloniti u roku od mjesec dana od dana primanja poziva. Ako podnositelj ne postupi po pozivu Instituta, prijava patenta kojoj je utvrđen datum podnošenja smatrat će se povučenom, o čemu se donosi poseban zaključak o obustavi postupka. Čl. 32., st. 5., 6.

67 Čl. 16. Pravilnika pobliže uređuje sadržaj registra prijava patenata. Registar prijava patenata je javan za prijave patenata koje su objavljene.
} 
Podnositelju prijave za priznanje patenta nije dano ovlaštenje da zahtjeva da se drugoj osobi zabrani da izum javno koristi i da zahtjeva naknadu štete jer se to pravo stječe tek priznanjem i registriranjem patenta. ${ }^{68}$

Podnositelj sukladno čl. 38. ZP, može, u roku od šest mjeseci od datuma objavljivanja prijave patenta u službenom glasilu, podnijeti zahtjev za:

a) priznanje patenta provedbom postupka potpunog ispitivanja prijave patenta, ili

b) priznanje patenta na osnovu prihvaćenih podnesenih rezultata potpunog ispitivanja prijave patenta, ili

c) odgodu provedbe postupka potpunog ispitivanja prijave patenta i dodjelu konsenzualnog patenta.

Ako u propisanom roku nije podnesen jedan od ovih zahtjeva i plaćene taksa i troškovi postupka, prijava patenta smatra se povučenom i Institut donosi zaključak o obustavljanju postupka za priznanje patenta. ${ }^{69}$

\section{a) priznanje patenta provedbom postupka potpunog ispitivanja prijave pa- tenta}

Cilj potpunog ispitivanja je provjeriti ispunjava li prijava i izum na koji se odnosi uvjetima koji se odnose na bit izuma koji su određeni čl. 39., st. 1. ZP. Postupak potpunog ispitivanja je najsloženiji dio postupka. ${ }^{70}$

Potpunim ispitivanjem prijave patenta utvrđuje se da li izum zadovoljava sve uvjete za

priznanje patenta, tj. je li predmet prijave izum: izum u smislu ZP, izum koji nije izuzet iz patentne zaštite, $u$ skladu s pravilom o jedinstvu izuma, dostatno jasan $\mathrm{i}$ potpuno opisan kako bi ga stručnjak mogao izvesti (primijeniti), koji je nov, ima inventivnu razinu i je li industrijski primjenjiv. ${ }^{71}$

Postupak potpunog ispitivanja prijave Institut može provesti u potpunosti ili djelomično u pravilu u suradnji s patentnim uredima iz čl. 32. Ugovora o suradnji u oblasti patenata (PCT), kao i patentnim uredima drugih zemalja koji provode

\footnotetext{
68 Vrhovni sud BiH, broj: Rev-147/86 od 28. 11. 1986. Godine - Bilten VSBiH, broj 1/87, odluka broj 8.

69 Sadržaj i forma zahtjeva za ispitivanje uvjeta za priznanje patenta određeno je čl. 22. Pravilnika.

$70 \quad$ Miladinović, Pravo industrijske svojine, str. 83.

71 Marković, Popović, Pravo intelektualne svojine, 2015., str.147.
} 
postupak potpunog ispitivanja i s kojima Institut o tome ima sklopljen ugovor o suradnji.

\section{b) priznanje patenta na osnovu prihvaćenih podnesenih rezultata potpunog ispitivanja prijave patenta}

Zahtjev za priznanje patenta prihvaćanjem rezultata potpunog ispitivanja priznatog patenta u skladu s čl. 38., st. 1. toč. (b) ZP može se podnijeti samo ako je prijava patenta za isti izum podnesena jednom ili većem broju patentnih ureda. ${ }^{72}$ Podnositelj tog zahtjeva obavezan je uz zahtjev priložiti potpisanu izjavu da će dokaz o rezultatu postupka potpunog ispitivanja provedenog $\mathrm{u}$ jednom od tih ureda dostaviti u roku od šest mjeseci od dana priznanja patenta od tog ureda, a najkasnije pet godina od datuma podnošenja zahtjeva. Ako podnositelj prijave u određenom roku ne dostavi rezultate provedenog postupka potpunog ispitivanja koji su Institutu dovoljni za donošenje rješenja u pogledu zahtjeva za priznanje patenta, prijava se smatra povučenom i Institut donosi zaključak o obustavljanju postupka.

Institut donosi rješenje po zahtjevu za priznanje patenta ako su ispunjeni uvjeti koji se odnose na bit izuma iz čl. 39., st.1. ZP na temelju uzimanja u obzir dostavljenih rezultata postupka potpunog ispitivanja. ${ }^{73}$

\section{c) odgoda provedbe postupka potpunog ispitivanja prijave patenta i dodjela konsenzualnog patenta}

Zahtjev za dodjelu konsenzualnog patenta objavljuje se u službenom glasilu. Svaka fizička ili pravna osoba može u roku od šest mjeseci nakon objavljivanja zahtjeva za dodjelu konsenzualnog patenta Institutu podnijeti prigovor protiv dodjele konsenzualnog patenta ili podnijeti zahtjev Institutu za provedbu postupka potpunog ispitivanja. Prigovoru se prilaže dokaz o plaćenim troškovima postupka za prigovor, koji iznosi jednu trećinu troškova postupka potpunog ispitivanja, kao i dokaz o plaćenim troškovima postupka za provedbu postupka potpunog ispitivanja. Ako se ispune ti uvjeti, Institut o tome bez odgađanja obavještava podnositelja zahtjeva za priznanje konsenzualnog patenta. Podnositelj zahtjeva

\footnotetext{
72 To su uredi koji provode postupak potpunog ispitivanja s kojima u trenutku podnošenja zahtjeva Institut o tome ima potpisan ugovor o suradnji, te državni i međudržavni uredi koji na osnovu članka 32. Ugovora o suradnji u oblasti patenata (PCT) imaju status ovlaštenog tijela za međunarodno prethodno ispitivanje međunarodnih prijava patenata. Čl. 40., st. 2. ZP.

73 Čl. 40., st. 6. ZP.
} 
za dodjelu konsenzualnog patenta može u roku od šest mjeseci od primanja obavijesti o podnesenom prigovoru podnijeti zahtjev za priznanje patenta provedbom postupka potpunog ispitivanja, pri čemu je dužan platiti razliku između uplaćene takse za podnošenje prigovora i takse propisane za provedbu postupka potpunog ispitivanja. Ako podnositelj zahtjeva za dodjelu konsenzualnog patenta ne postupi u skladu s tim, Institut će odbaciti prijavu patenta zaključkom. ${ }^{74}$

Za sve vrijeme trajanja konsenzualnog patenta, odnosno tijekom 10 godina trajanja, njegov nositelj, kao i svaka druga fizička ili pravna osoba mogu podnijeti zahtjev za provedbu postupka potpunog ispitivanja navedene prijave patenta. ${ }^{75}$ Nakon potpunog ispitivanja konsenzualni patent može se preoblikovati u redovni, uobičajeni patent koji traje 20 godina.

Temeljna specifičnost postupka za priznanje konsenzualnog patenta je u tome što, poslije provedenog postupka formalnog ispitivanja prijava, nema objavljivanja prijave niti suštinskog ispitivanja prijave. ${ }^{76}$

Uz uredno podnošenje zahtjeva predviđenog pod točkama a) ili b) i uplaćenih taksa i troškova postupka, Institut će nakon postupka potpunog ispitivanja prijave patenta ili dostavljenih rezultata provedenog postupka potpunog ispitivanja izvršenog od strane jednog ili većeg broja patentnih ureda, ocijeniti udovoljava li prijava patenta uvjetima patentibilnosti, te će u konačnici rezultirati ili ne rezultirati priznanjem patenta. Patent priznat za izum na jedan od navedenih načina predstavlja pravo industrijskog vlasništva koje je vremenski ograničeno na 20 godina računajući od datuma podnošenja prijave patenta. Patent koji se dodjeljuje (konsenzualni patent) na osnovu zahtjeva predviđenog pod točkom c) također je vremenski ograničeno pravo industrijskog vlasništva i traje 10 godina računajući od datuma podnošenja prijave patenta.

Institut će odbiti zahtjev za priznanje patenta ako je utvrđeno da prijava patenta ne ispunjava uvjete za priznanje patenta predviđene ZP-om. Institut u pisanoj formi izvještava podnositelja prijave o razlozima zbog kojih se patent ne može priznati i poziva ga da se u pisanoj formi izjasni o navedenim razlozima u određenom roku, koji ne može biti kraći od mjesec dana ni duži od dva mjeseca od dana primanja poziva. Ako podnositelj prijave ne postupi u skladu s tim pozivom, Institut donosi rješenje o odbijanju patenta.

Rješenje o odbijanju u pisanom obliku ispitivač će sastaviti na temelju prijave koju je ispitao, u pogledu oblika i sadržaja rješenja primijenit će odredbe ZUP. ${ }^{77}$

\footnotetext{
74 Čl. 42. ZP.

Sadržaj prigovora na zahtjev za dodjelu konsenzualnog patenta određen je čl. 24. Pravilnika.

76 Marković, Popović, Pravo intelektualne svojine, 2015., str. 149.

77 Metodologija, str. 84. -86.
} 
Institut će odobriti zahtjev za priznanje patenta ako je utvrđeno da prijava patenta ispunjava uvjete za priznanje patenta predviđene ZP-om i donijeti rješenje o priznanju patenta, odnosno konsenzualnog patenta.

Rješenje o priznanju zahtjeva ili odbijanju zahtjeva za priznanje patenta po svojoj je formi upravni akt ${ }^{78}$ i mora imati sljedeće sastavne dijelove: uvod, dispozitiv, obrazloženje, uputu o pravnom lijeku, potpis službene osobe i pečat Instituta. Uvod rješenja o priznanju patenta sadrži: naziv upravnog organa koji donosi rješenje, a to je Institut, propis o nadležnosti tog organa, ime stranaka, i njihovih zakonskih zastupnika ili punomoćnika ako ih imaju i kratko označenje predmeta postupka. Dispozitiv rješenja je njegov najvažniji dio. Dispozitivom se rješava o predmetu postupka i on mora biti kratak, jasan i određen, a kada je to potrebno može biti podijeljen u više točaka. Obrazloženje rješenja sadrži: kratko izlaganje zahtjeva stranaka, izvedene dokaze i utvrđeno činjenično stanje, razloge koji su bili odlučujući pri ocjeni dokaza, razloge zbog kojih nije ili jeste uvažen zahtjev stranke, odnosno razloge koji s obzirom na utvrđeno činjenično stanje upućuju na onakvo rješenje kakvo je dano u dispozitivu i pravne propise na temelju kojih je riješena upravna stvar. Uputa o pravnom lijeku služi da se stranka obavijesti može li protiv rješenja izjaviti pravni lijek (žalbu ili tužbu), kome ga izjavljuje, u kojem roku i s kolikom pristojbom predaje. Rješenje potpisuje službena osoba koja ga donosi, a stranci se izdaje u originalu ili ovjerenom prijepisu.

Protiv rješenja Instituta donesenog u prvom stupnju, nezadovoljna stranka može izjaviti žalbu u roku od 15 dana od dana dostave rješenja o odbijanju priznanja patenta Komisiji za žalbe Instituta za intelektualno vlasništvo. Sadržaj žalbe je određen čl. 98. ZP. Osim podataka koje mora imati svaki podnesak, žalba mora

78 U francuskoj teoriji Walline ističe da je upravni akt, akt upravne vlasti ili, iznimno, privatnih osoba s povlasticama javne vlasti, podoban za izvršenje zakona. Walline, M., Droit administratif, 9-e édition, Paris, 1963, str. 434.; Laubadère upravni akt definira kao „akt upravne vlasti koji se odnosi na pojedinca (akt uvjet ili subjektivni akt") (Laubadère, A. D., Manuel de droit administratif, Librairie générale de droit et de jurisprudence, Paris, 1955., str. 179.). U domaćoj teoriji Krbek definira upravni akt kao „autoritativno odlučenje radi izazivanja neposrednog pravnog efekta u pravima i dužnostima fizičkih i kolektivnih lica za konkretni slučaj na području upravne djelatnosti“" (Krbek, Ivo, Upravni akt, JAZU, Zagreb, 1960., str. 16.), a Borković kao „pravni akt kojim se u slučajevima predviđenim u pravnoj normi, od strane državnih organa odnosno pravnih osoba koje imaju javne ovlasti, na autoritativan i jednostran način odlučuje o pravima i obvezama pojedinih subjekata u konkretnoj upravnoj stvari. (Borković, Ivo, Upravno pravo, str. 328.). O pojmu upravnog akta, njegovim bitnim obilježjima i elementima više vidi: Krijan, Pero, Upravni postupak i upravni spor, Mostar, 1998, str. 121.; Krijan, Pero, „Pojam upravnog akta“, Informator, br. 5010 od 13. 3. 2002. godine i „Elementi upravnog akta“, Informator, br. 5011 od 16. 3. 2002. godine; Dedić, Sead, Upravno pravo Bosne i Hercegovine, Magistrat, Bihać - Sarajevo, 2001., str. 239. - 240. 
sadržavati: naznaku odluke protiv koje se podnosi, izjavu o tome da se odluka osporava u cijelosti ili u određenom dijelu, razloge zbog kojih se žalba podnosi, obrazloženje žalbe, te dokaze kojima podnositelj žalbe potvrđuje svoje navode iz žalbe, potpis podnositelja žalbe, punomoć ako se žalba podnosi posredstvom zastupnika.

Komisija za žalbe ima tri člana od kojih je jedan predsjedavajući i tri zamjenika člana. Članove Komisije za žalbe imenuje Vijeće ministara među neovisnim stručnjacima u oblasti prava industrijskog vlasništva i državnih službenika iz Instituta na način uređen odlukom Vijeća ministara. ${ }^{79}$ Predsjedavajući i članovi Komisije za žalbe neovisni su, nisu obvezani nikakvim uputama direktora Instituta i svoje zadatke obavljaju nepristrano i u skladu sa zakonom i pravilima struke. Članovi Komisije za žalbe i zamjenici članova koji su sudjelovali u donošenju odluke u prvostupanjskom postupku, ili kad postoje drugi razlozi za njihovo izuzimanje, ne mogu sudjelovati u postupku po žalbi u istom predmetu. Komisija za žalbe odlučuje na sjednicama većinom glasova, na osnovu podnesaka stranaka, a kada smatra da je to potrebno, može odrediti održavanje usmene rasprave (čl. 100. ZP). Rješavajući po žalbi, Komisija za žalbe može žalbu odbaciti, odbiti ili uvažiti i osporavano rješenje poništiti u cijelosti ili djelomično.

Protiv drugostupanjskog rješenja Komisije za žalbe nezadovoljna stranka može tužbom pokrenuti upravni spor ${ }^{80}$ pred Sudom $\mathrm{BiH}$ u roku od 30 dana od primitka odluke Komisije ${ }^{81}$.

Sjedište Komisije za žalbe je u sjedištu Instituta. Komisija za žalbe ima svoj pečat. Institut osigurava Komisiji za žalbe radni prostor i potrebnu opremu za obavljanje njihovih zadataka. Uredske i druge administrativne poslove za Komisiju za žalbe osigurava Institut. Čl. 99., st. 3. ZP. Pitanje Komisije za žalbe je detaljnije uređeno Odlukom o načinu izbora članova Komisije za žalbe Instituta za intelektualno vlasništvo, Službeni glasnik BiH, broj: $63 / 11$.

80 U domaćoj pravnoj literaturi Borković je upravni spor odredio kao oblik sudske kontrole nad upravom i to u prvom redu kontrole upravnog (pojedinačnog, individualnog) akta (Borkovć, Ivo, str. 483.), Dupelj upravni spor određuje kao spor o zakonitosti upravnog akta koji je postao konačan u upravnom postupku (Dupelj, Željko, „Upravni spor - oblik sudske kontrole nad upravnom“, Pravo i porezi, god. 7, br. 10, 1998., str. 30.). O upravnom sporu više u: Krbek, Ivo, „O upravnom sporu“, Hrestomatija upravnog prava, Društveno veleučilište u Zagrebu, Pravni fakultet u Zagrebu, Zagreb, 2003., str. 229. - 230. Upravni spor se na sličan način definira i u usporednom pravu. Usporedi: Jacobini, Horace B., An Introduction to Comparative Administrative Law, Oceana Publications, New York, London, 1991., str. 10.; Schwartze, Jurgen, „Judicial Review in EC Law: Some Reflections on the Origins and the Actual Legal Situation", International and Comparative Law Quarterly, vol. 51, no. 1, 2002., str. 18. objavljenom u Službenom glasniku BiH, br. 19/02. 
Podatci iz rješenja o priznanju patenta, odnosno dodjeli konsenzualnog patenta, $s$ datumom donošenja rješenja, upisuju se u Registar patenata koji u elektronskoj formi vodi Institut. ${ }^{82}$ Nositelju patenta izdaje se isprava o patentu na njegov zahtjev, a nositelju konsenzualnog patenta izdaje se isprava o konsenzualnom patentu. ${ }^{83}$ Također, nositelju patenta može se izdati patentni spis na vlastiti zahtjev. ${ }^{84}$ Rješenje o priznanju patenta, odnosno konsenzualnog patenta objavljuje se u službenom glasniku Instituta, koji se izdaje kvartalno. Rješenje o priznanju patenta ima učinak od datuma objave podataka o priznanju u službenom glasniku, čl. 48., st. 1. ZP.

Patentna zaštita može se pružiti samo osobi koja je izvršila prijavu svog pronalaska, odnosno patenta (izuma) i ako mu je to pravo priznato po postupku i na način propisan zakonom od nadležnog tijela za patente. ${ }^{85}$

\section{Svjedodžba o dodatnoj zaštiti (SDZ)}

Svjedodžba o dodatnoj zaštiti (SDZ) je specifično, posebno (sui generis) pravo na intelektualno vlasništvo koje djeluje kao produžetak patenta ${ }^{86}$ Vrijeme između prijave za patent za novi lijek ${ }^{87}$ ili sredstvo za zaštitu usjeva i primanja odo-

\footnotetext{
$82 \quad$ Čl. 45. ZP, i čl. 26. Pravilnika.

$83 \quad$ Čl. 46. ZP i čl. 29. Pravilnika.

$84 \quad$ Čl. 47. ZP i čl. 32. Pravilnika.
}

85 Vrhovni sud Republike Srpske, broj: Gž-4/03 od 3. 11. 2003., Bilten sudske prakse VS RS, broj 2004/I, odluka broj 94, str. 166-167, Domaća i strana sudska praksa, broj 6/2004, str. 41.

Svjedodžbe o dodatnoj zaštiti za lijekove i sredstva za zaštitu bilja, EUR Lex, dostupno na: https://eur-lex.europa.eu/legal-content/hr/LSU/?uri=CELEX:32009R0469, posjećeno: 23. siječnja 2019. SDZ pruža dodatnu zaštitu za određene farmaceutske proizvode i sredstva za zaštitu bilja koji imaju nacionalni patent i koji su odobreni za prodaju. Zaštita je oblikovana kako bi se ispravile bilo koje razlike i nedostaci u nacionalnim patentnim sustavima za zaštitu farmaceutskih i biljnih proizvoda. Temeljni dokumenti su: Uredba (EZ) br. 469/2009 Europskog parlamenta i Vijeća od 6. svibnja 2009. o svjedodžbi o dodatnoj zaštiti za lijekove (kodificirani tekst) (SL L 152, 16.6.2009., str. 1.-10.), Sukcesivne izmjene i dopune Uredbe (EZ) br. 469/2009 uključene su u osnovni tekst, Uredba (EZ) br. 1610/96 Europskog parlamenta i Vijeća od 23. srpnja 1996. o uvođenju svjedodžbe o dodatnoj zaštiti za sredstva za zaštitu bilja (SL L 198, 8.8.1996., str. 30. -35.).

87 U predmetu C527/17, (EU:C:2018:867), povodom zahtjeva za prethodnu odluku, koji je upućen u okviru postupka koji je Boston Scientific Ltd pokrenuo zbog odbijanja Deutsches Patent und Markenamta (Njemački ured za patente i žigove, Njemačka) da dodijeli svjedodžbu o dodatnoj zaštiti (SDZ), Sud je utvrdio kako pojam „lijeka” treba razliko- 
brenja za njegovu prodaju smanjuje učinkovito razdoblje zaštite patenta, zbog obveznih dugotrajnih ispitivanja i kliničkih ispitivanja koja su potrebna prije dobivanja regulatornog odobrenja. Cilj je svjedodžbe nadoknaditi to smanjenje učinkovite zaštite patenta za ta dva područja. ${ }^{88}$

ZP u čl. 58. određuje kako se Svjedodžba o dodatnoj zaštiti može izdati u slučaju kada je osnovni patent priznat za lijek namijenjen ljudima ili životinjama ili za sredstvo za zaštitu bilja, za čije je stavljanje u promet potrebno prethodno odobrenje nadležnog tijela. Osnovni patent je patent koji je nositelj odredio u postupku za dobivanje svjedodžbe o dodatnoj zaštiti i kojim se štiti proizvod kao takav ili postupak za dobivanje ili primjenu proizvoda. ${ }^{89}$

Predmet zaštite svjedodžbom je samo proizvod obuhvaćen odobrenjem za stavljanje u promet lijeka namijenjenog ljudima ili životinjama, odnosno sredstva za zaštitu bilja, i to za svaku primjenu tog proizvoda kao lijeka namijenjenog ljudima ili životinjama, odnosno sredstva za zaštitu bilja, koja je bila odobrena prije prestanka važenja svjedodžbe. Učinci svjedodžbe nastupaju odmah nakon zakonskog isteka roka trajanja osnovnog patenta. Svjedodžba o dodatnoj zaštiti nositelju osigurava ista prava koja proizlaze iz patenta $i$, analogno, ta su prava

vati od pojma „medicinskog proizvoda”. Potonji pojam definiran je u članku 1. stavku 2. točki (a) Direktive 93/42 tako da se njime obuhvaća svaki instrument, uređaj, naprava, programska podrška, materijal ili drugi predmet, bilo da se koristi sam ili u kombinaciji, a koje je proizvođač namijenio za uporabu na ljudima u svrhu, među ostalim, dijagnosticiranja, sprečavanja, praćenja, liječenja ili ublažavanja bolesti, tjelesnog oštećenja ili nedostatka, i koji ne postiže svoje glavno namijenjeno djelovanje u ili na ljudskom tijelu farmakološkim, imunološkim ili metaboličkim sredstvima, ali mu takva sredstva mogu pomoći u njegovoj funkciji. Pojmovi „lijek” i „medicinski proizvod” isključuju, dakle, jedan drugi tako da se proizvod koji se može definirati kao „lijek” u smislu Direktive 2001/83 ne može razvrstati kao medicinski proizvod u smislu Direktive 93/42.

European Commission, Internal Market, Industry, Entrepreneurship and SMEs, Industry, Intellectual property, Patent protection in the EU, Supplementary protection certificates for pharmaceutical and plant protection products, Supplementary protection certificates, dostupno na: http://ec.europa.eu/growth/industry/intellectual-property/patents/supplementary-protection-certificates/, posjećeno: 29. siječnja 2019.

Odredbom članka 12. Nacrta Zakona predviđene su izmjene ovog članka na način da se ostvari terminološka usklađenost s kodificiranom verzijom Uredbe (EZ) 469/09 Europskog parlamenta i Vijeća od 6. svibnja 2009. godine, koja se odnosi na uređenje instituta Svjedodžbe o dodatnoj zaštiti za lijekove namijenjene ljudima ili životinjama. Novi članak daje definiciju lijeka, proizvoda, temeljnog patenta i svjedodžbe. Kodificirana verzija Uredbe (EZ) 469/09 ukinula je Uredbu (EZ) 1768/92, koja je bila relevantna za predmetni institut u vrijeme donošenja Zakona o patentu, pa se ovim izmjenama postiže usuglašenost s navedenom važećom Uredbom 469/09. 
podložna istim ograničenjima. ${ }^{90}$ Sukladno čl. $60 . \mathrm{ZP},{ }^{91}$ Svjedodžba se izdaje na zahtjev nositelja osnovnog patenta ako su na dan podnošenja zahtjeva za izdavanje svjedodžbe ispunjeni uvjeti određeni čl. 60. ZP.92

$\mathrm{U} \mathrm{BiH}$ odobrenje za promet lijekova izdaje Agencija za lijekove i medicinska sredstva, ${ }^{93}$ a odobrenje za promet herbicida i fungicida izdaje Ministarstvo poljoprivrede.

Institut u službenom glasilu objavljuje podatke o podnesenom zahtjevu za izdavanje svjedodžbe, donošenju rješenja o izdavanju svjedodžbe, odnosno odbijanju zahtjeva za izdavanje svjedodžbe i o prestanku važenja svjedodžbe. ${ }^{94}$

SDZ nije produženje patenta, već je posebno pravo koje je po sadržaju isto kao patent, ali se razlikuje po predmetu zaštite. ${ }^{95}$

\section{Međunarodna prijava prema ugovoru o suradnji u oblasti patenata (PCT)}

Ugovor o suradnji u oblasti patenta (PCT) predstavlja poseban međunarodni sporazum u smislu čl. 19. PK-a, zaključen 1970. u Washingtonu. BiH je članica

$90 \quad$ Čl. 59. ZP.

91 Odredbom članka 14. Nacrta Zakona uvodi se novi čl. 62. (a) kojim se pojašnjava način i uvjeti pod kojima se može održavati u važnosti Svjedodžba o dodatnoj zaštiti za lijekove namijenjene ljudima ili životinjama i postupanje Instituta u postupku nakon izdavanja svjedodžbe. Godišnja pristojba i troškovi postupka za održavanje u važenju svjedodžbe plaćaju se Institutu za svaku godinu njena važenja, koja se odnosi na 12-mjesečno razdoblje koje počinje teći od datuma prestanka važenja temeljnog patenta i naplaćuje se posebno za svaku godinu. Regulira se i situacija ako je posljednje razdoblje trajanja svjedodžbe kraće od dvanaest mjeseci, dodatni rok za plaćanje, kao i mogućnost da Institut uputi obavijest nositelju o propuštenim radnjama.

92 Odredbom čl. 13. Nacrta Zakona mijenja se članak 60. ZP-a koji uređuje uvjete za stjecanje svjedodžbe o dodatnoj zaštiti, na način da se dodaju dvije nove točke koje će urediti i terminološki usuglasiti članak s kodificiranom verzijom Uredbe (EZ) 469/09.

93 To pitanje je uređeno Zakonom o lijekovima i medicinskim sredstvima, Službeni glasnik $\mathrm{BiH}$, broj 58/08, Pravilnik o postupku i načinu davanja dozvole za stavljanje lijeka u promet, Službeni glasnik BiH, broj 75/2011.

94 Čl. 40., 41., 42. I 43. Pravilnika detaljnije uređuju SDZ. Odredbe iz čl. 58. do 63. ZP-a koje se odnose na SDZ ne primjenjuju se na konsenzualni patent.

95 Patent se odnosi na patentirani izum, a SDZ samo na konkretan proizvod za koji je dobivena dozvola za proizvodnju i promet. Marković, Popović, Pravo intelektualne svojine, 2015., str. 170. 
PCT od 7. prosinca 1996. PCT sustav predstavlja sustav podnošenja prijave patenta, a ne sustav priznanja patenta. Patent mogu priznati samo nacionalni uredi i regionalne patentne organizacije. ${ }^{96}$

Međunarodna prijava je prijava koja se podnosi u skladu s Ugovorom u suradnji u oblasti patenata (PCT). Svako pozivanje na PCT u ZP-u smatra se, ujedno, pozivanjem i na odredbe Pravilnika u skladu sa PCT-om. Na međunarodne prijave koje se Institutu podnose kao prijemnom uredu, ili u kojima je Institut naveden kao naznačeni ili izabrani ured, primjenjuju se odredbe PCT-a, ZP-a i propisa donesenih na osnovu ZP-a. ${ }^{97}$

Institut može u PCT sustavu imati ulogu prijemnog ureda, kako je određeno čl. 82. ZP.9 ${ }^{98}$ Druga, odnosno treća mogućnost prema PCT sustavu određena je čl. 83. ZP-a, kada se međunarodna prijava patenta koja se Institutu podnosi kao naznačenom ili izabranom_uredu. ${ }^{99} \mathrm{Kad}$ je $\mathrm{BiH}$ naznačena kao država u postupku iz

96 „Uputstvo za podnošenje međunarodne prijave patenta, u skladu s ugovorom o saradnji u oblasti patenta", Patent Cooperation Treaty (PCT), Zavod za intelektualnu svojinu Republike Srbije i WIPO, str. 2., dostupno na: http://www.zis.gov.rs/upload/documents/pdf_sr/ pdf_patenti/uputstvo_PCT.pdf, posjećeno: 25. siječnja 2019. Čl. 81. ZP. Međunarodna prijava se može podnijeti Institutu kao prijemnom uredu ako je podnositelj prijave državljanin $\mathrm{BiH}$ ili fizička osoba koja u $\mathrm{BiH}$ ima prebivalište ili pravna osoba koja ima svoje sjedište u $\mathrm{BiH}$. Za podnošenje međunarodne prijave, koja se podnosi na engleskom jeziku, plaćaju se propisana taksa i troškovi postupka za prosljeđivanje Međunarodnom uredu, u roku utvrđenom odredbama PCT (Pravilo 14. PCT Pravilnika). Europski patentni ured je ovlašteno tijelo za međunarodno pretraživanje i ovlašteno tijelo za međunarodno prethodno ispitivanje. Više vidjeti: Metodologija, str. 87. „Administrative instructions under the Patent Cooperatation Treaty" (as in force January 1, 2019), WIPO, str. 8., dostupno na: https://wipolex.wipo.int/en/text/501187, posjećeno: 26. siječnja 2019. Međunarodna prijava u kojoj je $\mathrm{BiH}$, u skladu s odredbama PCT, naznačena ili izabrana radi priznanja nacionalnog patenta, za koju su plaćeni taksa i naknada troškova, podnosi se Institutu na jednom od jezika koji su u službenoj upotrebi u $\mathrm{BiH}$ najkasnije do isteka 34 mjeseca, računajući od međunarodnog datuma podnošenja, odnosno datuma prvenstva ako je u međunarodnoj prijavi zahtijevano prvenstvo. Međunarodna prijava koja je Institutu podnesena kao naznačenom ili izabranom uredu objavljuje se u službenom glasilu u skladu sa ZP-om. Privremena prava u skladu sa ZP-om podnositelj međunarodne prijave u kojoj je $\mathrm{BiH}$, u skladu s odredbama PCT-a, naznačena ili izabrana radi priznanja nacionalnog patenta, stječe datumom objavljivanja prijave patenta na jednom od jezika koji su u službenoj upotrebi u BiH. Za ove prijave rok u kojem se može podnijeti jedan od zahtjeva priznanje patenta provedbom postupka potpunog ispitivanja prijave patenta ili priznanje patenta na temelju prihvaćenih podnesenih rezultata potpunog ispitivanja ili zahtjev za odgodu provedbe postupka potpunog ispitivanja i dodjelu konsenzualnog patenta, počinje teći od datuma objavljivanja u službenom glasilu. 
Poglavlja I. PCT-a, rezultati postupka kojima se služe strani i domaći podnositelji međunarodnih prijava su: međunarodna objava prijave, izvješće o međunarodnom pretraživanju, pisano izvješće o patentibilnosti. Ako je, pak, $\mathrm{BiH}$ izabrana država u postupku iz poglavlja II. PCT-a, postupak se provodi po slobodnom izboru podnositelja prijave. Rezultat postupka je izvješće o međunarodnom prethodnom ispitivanju.

\section{Regionalna (europska) zaštita}

\subsection{Sporazum o suradnji i proširenju i EPC}

Sporazum o suradnji i proširenju između Vijeća ministara Bosne i Hercegovine i Europske patentne organizacije stupio je na snagu 1. prosinca 2004. ${ }^{100}$ Omogućava proširenje zaštite koja proizlazi iz europskih prijava i europskih patenata na države koje još nisu potpisnice Evropske patentne konvencije (EPC). Sporazum o suradnji i proširenju je temelj proširenja koji podnositeljima prijava omogućava dobivanje patentne zaštite u državama proširenja, na jednostavan i isplativ način.

Predloženim izmjenama i dopunama Zakona o patentu, područje patentnopravne zaštite bit će usklađeno s aktualnom pravnom stečevinom EU, odnosno uskladit će se odredbe važećeg ZP-a kojima je uređeno područje proširenog europskog patenta s izmjenama Europske patentne konvencije iz 2000te godine, praksom koja proizlazi iz primjene navedene konvencije, a u cilju implementiranja Sporazuma o suradnji i proširenju. ${ }^{101}$

Europska patentna organizacija (EPO) kroz Program bilateralne suradnje (BCP) $s$ Institutom osigurava pomoć za daljnji razvoj infrastrukture za uspostavu učinkovitog patentnog sustava u BiH. ${ }^{102}$

100 Sporazum o suradnji i proširenju između Vijeća ministara Bosne i Hercegovine i Europske patentne organizacije, Službeni glasnik BiH - Međunarodni ugovori, br. 2/04.

Kroz primjenu važećeg zakonskog teksta, uočeni su određeni nedostatci, odnosno pojedine norme su nejasne i neprecizne, stoga je nužna njihova dorada i prilagodba potrebama prakse, čime će se osigurati učinkovita primjena propisa i veća pravna sigurnost. Također, uvode se odredbe za povjerljivi pronalazak i postupanje Instituta u slučaju zaprimanja prijave patenta za pronalazak koji se odnosi na obranu i sigurnost države. Vidjeti: „Razlozi za donošenje zakona“, Prednacrt Zakona o izmjenama i dopunama zakona o patentu, Institut za intelektualno vlasništvo, Mostar, siječanj 2018.

102 Program predviđa između ostaloga, osiguranje osnovnih treninga za europski patentni sustav ustanovljen Konvencijom o europskom patentu i Unitarni patent odnosno sustav 


\subsection{Prošireni europski patent (EPC)}

Patentna zaštita izuma u EU počiva na nacionalnom pravu država članica. Bez obzira na to jesu li ih odobrili nacionalni patentni uredi ili Europski patentni ured, pravo iskorištavanja patentiranog izuma je teritorijalno ograničeno, čiju supstancu određuje svaka država autonomno. ${ }^{103}$

Na zahtjev podnositelja prijave i nakon plaćanja takse za proširenje, europske prijave patenata i europski patenti mogu se proširiti na $\mathrm{BiH}$ gdje će imati iste učinke kao i nacionalne prijave i nacionalni patenti, čl. od 84. do 92. ZP. Oni će imati potpuno isti opseg zaštite kao i patenti što ih je priznao EPO za države ugovornice EPO. Europske prijave mogu biti prijave europskog patenta podnesene neposredno ili prijave europskog patenta podnesene prema PCT-u. Europski patenti mogu također imati učinka i u nekim zemljama koje nisu pristupile EPC (države proširenja). ${ }^{104}$

Sustav proširenja u velikoj se mjeri podudara sa sustavom koji se prema EPC-u primjenjuje u državama ugovornicama EPC-a. Međutim, on se ne temelji na neposrednoj primjeni EPC-a, već samo na nacionalnom pravu uređenom prema EPC-u. Prema tome, u BiH se sustav proširenja primjenjuje u skladu s nacionalnim pravilima o proširenju. Taksa za proširenje neposredno se plaća EPO-u, čl. 86. ZP-a. Zahtjev za proširenje smatra se povučenim ako nije plaćena taksa za proširenje ili ako je prijava povučena, odbijena ili ako se smatra povučenom, čl. 85. st. 3. ZP-a. ${ }^{105}$

$\mathrm{ZP} \mathrm{u}$ desetom dijelu regulira Prošireni europski patent (EPC) u čl. 84. do 92. ${ }^{106}$

patenta Zajednice, čije je uvođenje najavljeno. Vidjeti: „Program rada Instituta za intelektualno vlasništvo BiH za 2019. godinu“, Mostar, 25.7.2018., str. 1. Lamping, Ullrich, The Impact of Brexit on Unitary Patent Protection and its Court, str. 7. Članice ove konvencije mogu biti i europske zemlje koje nisu članice Europske unije, te je trenutno zaštita ovim putem moguća u čak 38 europskih zemalja, a kroz dodatne oblike proširenja ovog sustava i za još neke europske i neeuropske zemlje. Regionalna (europska) zaštita, Zaštita intelektualnog vlasništva, Patenti, Državni zavod za intelektualno vlasništvo Republike Hrvatske, dostupno na: http://www.dziv.hr/hr/intelektualno-vlasnistvo/ patenti/regionalna-zastita/, posjećeno: 26. siječnja 2019. Kao i: European patents and the grant procedure, EPO, str. 14., dostupno na: http://documents.epo.org/projects/babylon/ eponet.nsf/0/7BFD01F37A47BA47C1257FED004EF089/\$File/european_patents_and_ the_grant_procedure_2018_en.pdf, posjećeno: 27. siječnja 2019. Metodologija, str. 90.

106 I to Proširenje učinka europskog patenta, zahtjev za proširenje, taksa za proširenje, Učinke europskih prijava patenata, učinke proširenih europskih patenata, vjerodostojan tekst europske prijave patenta ili europskog patenta, prava ranijeg datuma, istovremenu zaštitu, takse za održavanje proširenih europskih patenata. 
Odredbom članka 24. Nacrta Zakona uvodi se novo poglavlje "Dio deseti A Europski patent (EPC), u osnovni tekst Zakona uređivanjem, u čl. 92. (a) do 92. (n), europskog patenta i europske prijave patenta sukladno Europskoj patentnoj konvenciji (EPC), a za prijave europskog patenta u kojima je naznačena BiH. Pored novog poglavlja koje je predviđeno Nacrtom, mijenjaju se i odredbe koje su dio desetog poglavlja postojećeg ZP-a. ${ }^{107}$ Tako će se osigurati usklađenost s promjenama uvedenim EPC iz 2000. u vezi sa Sporazumom o suradnji i proširenju tj. utjecaju izmjena EPC-a na primjenu navedenog Sporazuma. Precizira se rok i radnje za naznaku proširenja europskog patenta. ${ }^{108}$

Do stupanja na snagu Sporazuma o suradnji i proširenju s EPO (1. prosinac 2004.), međunarodne prijave podnesene putem PCT mogle su ući u nacionalnu fazu u BiH samo direktno. ${ }^{109}$ Nakon stupanja na snagu tog sporazuma, podnositelj međunarodne prijave putem PCT-a može nakon međunarodne faze prema PCT izabrati i regionalnu rutu Euro-PCT. U tom slučaju, ako podnositelj odabere regionalnu rutu, prijava podnesena putem PCT-a bit će predmetom postupka za priznanje europskog patenta pred EPO. Ako EPO prizna patent, nositelj europskog patenta tada može na zahtjev taj patent proširiti u BiH. Podnositelj prijave ako ne želi ići na regionalnu rutu, može izravno ući u nacionalnu fazu u $\mathrm{BiH}$ (bez rute Euro-PCT). ${ }^{110}$ Dakle, iako je putem PCT olakšano podnošenje prijave, odlu-

107 Vidjeti: „Razlozi za donošenje zakona“, Prednacrt Zakona o izmjenama i dopunama zakona o patentu, Institut za intelektualno vlasništvo, Mostar, siječanj 2018.

Precizira se sadržaj zahtjeva za upis proširenog europskog patenta u Registar patenata i pravni učinci proširenog europskog patenta i prijave na temelju koje je patent priznat, kao i važeće odredbe kojom je uređen institut vjerodostojnosti teksta europske prijave ili europskog patenta. Predviđena je i izmjena stavaka 1. članka 90. čime se izjednačava učinak na stanje tehnike europske prijave i proširenog europskog patenta u odnosu na nacionalnu prijavu i nacionalni patent, kao što je predviđena izmjena čl. 90. ZP-a kako bi se pojasnila situacija koja može nastati u slučaju da europski patent i nacionalni patent imaju isti datum podnošenja ili za slučaj kada je zatraženo pravo prvenstva, isti je datum prvenstva priznat istoj osobi ili njegovom pravnom sljedniku. Uz odredbu čl. 90. ZP-a, uvodi se novi članak 91. (a) kako bi se pojasnila primjena propisa EPC i provedbenih propisa uz EPC u postupcima za priznanje proširenog europskog patenta sukladno odredbama Dijela deset ZP-a. EPO predlaže da se odredbe EPC-a i provedbenih propisa uz nju ne primjenjuju u postupcima po zahtjevu za proširenje europskog patenta, tj. predlažu da bi primjena odredaba EPC bila moguća jedino i iznimno kada bi to bilo predviđeno pojedinim odredbama Zakona.

U roku od 34 mjeseca od datuma međunarodnog podnošenja, odnosno datuma prvenstva.

110 Više vidjeti: „Uputstvo za podnošenje međunarodne prijave patenta, U skladu sa ugovorom o saradnji u oblasti patenta“, Patent Cooperation Treaty (PCT), Zavod za intelektualnu svojinu Republike Srbije i WIPO, str. 2., dostupno na: http://www.zis.gov.rs/upload/ documents/pdf_sr/pdf_patenti/uputstvo_PCT.pdf, posjećeno: 25. siječnja 2019. Radi se 
ku o dodjeli patenta donijet će nacionalni ured u nacionalnoj fazi postupka koja se obavlja prema pravilima te zemlje,odnosno regionalni ured u regionalnoj fazi postupka prema pravilima te regionalne organizacije. ${ }^{111}$

Dakle, strani ili domaći podnositelj prijave može na tri načina, odnosno preko tri različite rute ostvariti patentna prava $\mathrm{u} \mathrm{BiH}$. Razlikujemo tri različite rute: nacionalnu, europsku i međunarodnu. ${ }^{12}$

Sve države članice EU su i ugovornice Europske patentne konvencije, stoga je punopravno članstvo u Europskoj patentnoj organizaciji zahtijevani standard bez kojeg je nema članstva u EU. ${ }^{113}$

o regionalnom sustavu kojeg karakterizira viši stupanj integracije patentnog prava više država no što je to slučaj kod međunarodne prijave, iako i europska prijava rezultira nacionalnim patentima. Matanovac Vučković, Ernst, Prava na izumu koja mogu biti predmet ovrhe - hrvatska, europska i međunarodna perspektiva, str. 31.; Metodologija, str. 87.; „Kako ostvariti europski patent“, Vodič za prijavitelje, EPO, dio 1, jedanaesto izdanje, prosinac 2007., str. 13.

Vidjeti: Međunarodna prijava patenta (PCT), Zaštita intelektualnog vlasništva, Patenti, Državni zavod za intelektualno vlasništvo Republike Hrvatske, dostupno na: http://www. dziv.hr/hr/intelektualno-vlasnistvo/patenti/medunarodna-zastita/medunarodna-prijava-patenta/, posjećeno: 25. siječnja 2019.

U prvoj se nacionalna prijava podnosi Institutu. Druga, europska ruta ostvaruje se podnošenjem europske prijave patenta EPO ili nacionalnom uredu države ugovornice EPC kao prijemnom uredu. Kada se podnosi europska prijava, koja se želi proširiti na teritorij $\mathrm{BiH}$, podnositelj prijave mora naznačiti $\mathrm{BiH}$ kao državu proširenja i platiti taksu za proširenje. U trećoj, međunarodnoj ruti, podnosi se međunarodna prijava jednom od prijemnih ureda prema PCT-u (primjerice: državljani $\mathrm{BiH}$ mogu međunarodnu prijavu podnijeti Institutu kao prijemnom uredu). Nakon završetka međunarodne faze prema PCT-u (34 mjeseca od datuma prvenstva), međunarodna prijava može slijediti jednu od 2 različite rute: ulazak u regionalnu fazu Euro-PCT podnošenjem pri EPO-u, ili izravan ulazak u nacionalnu fazu podnošenjem prijave $\mathrm{u} \mathrm{BiH}$. O rutama podnošenja prijave vidjeti: „Your Guide to IP in Europe", The European IPR Helpdesk, Rhe essentials of IP protection in Europe, str. 19., 20.; „Kako ostvariti europski patent“, Vodič za prijavitelje, EPO, dio 1, jedanaesto izdanje, prosinac 2007., str. 11.; Metodologija, str. 90. Vidjeti i: Matanovac Vučković, Ernst, Prava na izumu koja mogu biti predmet ovrhe - hrvatska, europska i međunarodna perspektiva, str. 30 .

U travnju 2011. Komisija je iznijela prijedloge za europski patent jedinstvenog učinka (,jedinstveni patent") u okviru pojačane suradnje (IP/11/470) i (MEMO/11/240). U prosincu 2012. Europski parlament i Vijeće postigli su dugo iščekivani sporazum o jedinstvenom europskom patentnom paketu, kojim je omogućeno potpisivanje međunarodnog sporazuma o Jedinstvenom sudu za patente. Zadnji projekt na razini EU se temelji na Uredbi (EU) br. 1257/2012 Europskog parlamenta i Vijeća od 17. prosinca 2012. o provedbi poboljšane suradnje u području stvaranja jedinstvene zaštite patenta (SL 361/1, 17.12.2012., str. 1. - 8.) i Uredbi Vijeća (EU) br. 1260/2012 od 17. prosinca 2012. o provedbi poja- 
PEHAR, S., VIDIĆ M., JURKOVIĆ, C., Postupak za priznanje patenta u pravu Bosne i Hercegovine Zbornik radova Pravnog fakulteta Sveučilišta u Mostaru, br. XXVII., 2019., str. 5. - 36.

Detaljan prikaz i analiza ovog dijela prelazi okvire teme ovog rada, ali je bilo nužno ukazati na mogućnosti koje su predviđene ZP.

\section{Proglašavanje rješenja o priznanju patenta ništavnim}

Rješenje o priznanju patenta može se proglasiti ništavnim u svako doba po službenoj dužnosti ili na prijedlog zainteresirane osobe ili pravobranitelja $\mathrm{BiH}$ ili ombudsmena $\mathrm{BiH}$, ako je priznat: a) za predmet zaštite koji se ne može zaštititi patentom, b) za izum koji na datum podnošenja prijave patenta, odnosno na datum priznatog prvenstva, nije bio nov ili nije imao inventivni nivo, c) za izum koji nije industrijski primjenjiv, d) za izum koji nije otkriven na dovoljno jasan i detaljan način, tako da ga stručna osoba iz odgovarajuće oblasti tehnike može izvesti, uključujući i slučaj nedostupnosti živog biološkog materijala u nadležnoj ustanovi, e) za predmet zaštite koji izlazi van sadržaja prijave patenta kakva je podnesena, ili ako je patent priznat na osnovu izdvojene prijave koja izlazi van sadržaja prijave kakva je podnesena, f) na ime lica koje nije imalo pravo na patentnu zaštitu izuma. ${ }^{114}$

čane suradnje u području stvaranja jedinstvene patentne zaštite u pogledu primjenjivih aranžmana prevođenja SL L 361, 31.12.2012., str. 89. - 92.Vezani dokumenti su: Odluka Vijeća 2011/167/EU od 10. ožujka 2011. o odobravanju pojačane suradnje u području stvaranja zaštite jedinstvenim patentom (SL L 76, 22.3.2011., str. 53. - 55.). Uredbom 1260/2012 uspostavljaju se aranžmani prevođenja za 26 država članica EU-a koje su preuzele sustav europskog patenta s jedinstvenim učinkom (poznat kao „jedinstveni patent”). Uredba 1260/2012 počet će se primjenjivati četiri mjeseca od polaganja 13. instrumenta ratifikacije Sporazuma o Jedinstvenom sudu za patente. O projektima stvaranja unitarnog patenta vidjeti: Urlich, Hanns, „Harmonizing Patent Law: The Untamable Union Patent“, Max Planck Institute for Intellectual property and Competition law, research Paper No. 12 - 03, str. 5.; Kaesling, The European Patent with Unitary Effect - A Unitary Patent protection for a unitary market?, str. 2.; Plomer, A., „A Unitary Patent for a (Dis)United Europe: The Long Shadow of History“, Springer, CrossMark, IIC (2015) 46:508-533, str. 509.; „Pravosuđe za rast: Komisija popunjava pravne praznine za jedinstvenu zaštitu patenta“, Europska Komisija, Bruxelles, 29. srpnja 2013.; Xenos, Dimitros, „The European Unified patent Court: Assessment and Implications oft he Federalisation oft he Patent System in Europe“, Volume 10, Issue 2, August 2013, str. 247.; „Pravosuđe za rast: Komisija popunjava pravne praznine za jedinstvenu zaštitu patenta", Europska Komisija, Bruxelles, 29. srpnja 2013. Također, Rezolucija Europskog parlamenta od 26. svibnja 2016. o strategiji jedinstvenog tržišta (2015/2354(INI)), Matanovac Vučković, Romana, „Hrvatska i Makedonija u europskom patentnom sustavu“, Zbornik Pravnog fakulteta u Zagrebu, Vol. 61, No. 2, 2011., str. 679. 
Postupak za proglašavanje rješenja o priznanju patenta ništavnim pokreće se podnošenjem prijedloga Institutu. ${ }^{115}$

Ako prijedlog za proglašavanje rješenja o priznanju patenta ništavnim nije sastavljen u skladu sa ZP-om ili ako nisu plaćeni taksa i troškovi, Institut poziva podnositelja da u roku od mjesec dana od dana primanja poziva otkloni nedostatke. Ako ne uredi prijedlog u roku koji je određen, Institut odbacuje prijedlog. Institut dostavlja uredan prijedlog nositelju patenta i poziva ga da u roku koji ne može biti kraći od jednog ni duži od dva mjeseca od dana njegovog primanja dostavi svoj odgovor.

U postupku za proglašavanje rješenja o priznanju patenta ništavnim Institut poziva stranke da u roku koji ne može biti kraći od jednog ni duži od dva mjeseca da dostave svoje primjedbe na podneske druge stranke. Kada je potrebno, Institut ujedno poziva nositelja patenta da podnese opis, patentne zahtjeve i crteže u izmijenjenom obliku, pod uvjetom da predmet zaštite ne izlazi van sadržaja patenta kakav je priznat. Ako ocijeni da je to nužno zbog utvrđivanja činjenica bitnih za donošenje odluke, Institut može održati usmenu raspravu. Ako je podnesen prijedlog za proglašavanje rješenja o dodjeli konsenzualnog patenta ništavnim i kada su priloženi dokazi dovoljni za vjerojatnost da konsenzualni patent ne zadovoljava uvjete u skladu sa ZP-om, odgovor na poziv mora sadržavati i zahtjev za provedbu postupka potpunog ispitivanja. ${ }^{116}$

Osoba koja povrijedi pravo iz prijavljenog ili zaštićenog izuma ili ga neovlašteno koristi odgovara za štetu prema općim pravilima. Takvu zaštitu sud ne može pružiti izumitelju ako je rješenje o priznanju prava na patent oglašeno ništavnim u upravnom postupku. ${ }^{117}$ Međutim, vođenje upravnog postupka za poništenje patenta ne obvezuje parnični sud u parnici radi zaštite izuma na prekid postupka. ${ }^{118}$

U skladu s čl. 96. ZP-a, na osnovu rezultata provedenog postupka, Institut donosi rješenje o proglašavanju rješenja o priznanju patenta ništavnim, u potpunosti ili djelomično, ili rješenje kojim se prijedlog odbija. ${ }^{119}$

115 Prijedlog mora sadržavati podatke o podnositelju prijedloga, nositelju patenta, broj rješenja i registarski broj patenta, razloge zbog kojih se predlaže proglašavanje patenta ništavim s potrebnim dokazima.

116 Čl. 95. ZP.

117 Privredni sud Hrvatske, Pž-2619/92 od 9. 2. 1993. Pregled sudske prakse iz oblasti zaštite prava intelektualnog vlasništva, Sarajevo 2014., str. 102. VTS RH, Pž-1894/98, od 12. 1. 1999. Pregled sudske prakse iz oblasti zaštite prava intelektualnog vlasništva, Sarajevo 2014., str. 234. 


\section{Zaključak}

Postupak za stjecanje, održavanje, prestanak i evidenciju prometa patenta, odnosno konsenzualnog patenta vodi Institut za intelektualno vlasništvo Bosne i Hercegovine

Zaključno možemo reći da postupak priznanja patenta ima sedam faza, Prva je faza podnošenje prijave Institutu. Druga je formalno ispitivanje prijave u Institutu. Zatim slijedi treća faza: objava prijave patenta u Službenom glasniku Instituta. Četvrta faza je zahtjev podnositelja prijave Institutu o vrsti ispitivanja patentne prijave. Podnositelj prijave patenta, u roku od šest mjeseci od nadnevka objave prijave patenta u Službenom glasniku, podnosi zahtjev za: a) priznanje patenta provedbom postupka potpunog ispitivanja prijave patenta u Institutu, ili b) priznanje patenta na temelju prihvaćenih podnesenih rezultata potpunog ispitivanja prijave patenta od nekog drugog tijela, ili c) odgodu provedbe postupka potpunog ispitivanja prijave patenta i dodjelu konsenzualnog patenta. Peta faza je ispitivanje prijave patenta od strane Instituta ili dostavljenih rezultata provedenog postupka potpunog ispitivanja izvršenog od strane jednog ili većeg broja patentnih ureda, te ocjena udovoljava li prijava patenta uvjetima patentibilnosti, što će u konačnici rezultirati ili ne rezultirati priznanjem patenta. Šesta faza je donošenje rješenja o priznanju patenta u Institutu. Patent priznat za izum na jedan od navedenih načina pod točkama a) ili b) predstavlja pravo industrijskog vlasništva koje je vremenski ograničeno na 20 godina računajući od datuma podnošenja prijave patenta. Patent koji se dodjeljuje (konsenzualni patent) na osnovu zahtjeva predviđenog pod točkom c) je također vremenski ograničeno pravo industrijskog vlasništva i traje 10 godina računajući od datuma podnošenja prijave patenta. I posljednja, sedma faza je objava patenta u Službenom glasniku Instituta.

prijenosu prava, odnosno ustupanju licence ako su i u mjeri u kojoj su ti ugovori izvršeni pod uvjetom da je tužitelj, odnosno nositelj prava patenta postupao savjesno. 


\section{PATENT GRANTING PROCEDURE IN THE LAW OF BOSNIA AND HERZEGOVINA}

Summary: Patent granting and protection procedures are complex, long-lasting, difficult and expensive. The acquisition, maintenance, content, recording of transfer, cessation and the protection of a patent in B\&H is regulated by the Patent Law and the Regulations Concerning Procedure for the Grant of a Patent and a Consensual Patent.

Patent granting procedure is an administrative procedure that is conducted by The Institute for Intellectual Property of Bosnia and Herzegovina. The process issues that are not regulated by the Patent Law of Bosnia and Herzegovina or the Regulations Concerning Procedure for the Grant of a Patent and a Consensual Patent, are then regulated by the Administrative Procedure Law.

Although the three material legal conditions that must be met in order for the invention to be patented are universally accepted, the right to exploit the patented invention is still territorially limited, so the protection of a patent in the EU is regulated on the national level of each member states. Apart from the Patent Register, the Institute for Intellectual Property of Bosnia and Herzegovina monitors the Register for Patent Application. Therefore, the paper analyses the significance of patent application and the specificities of the patent granting procedure, which is regulated by a specific law.

Key words: invention, patent, administrative procedures, patent application, Institute for intellectual property. 